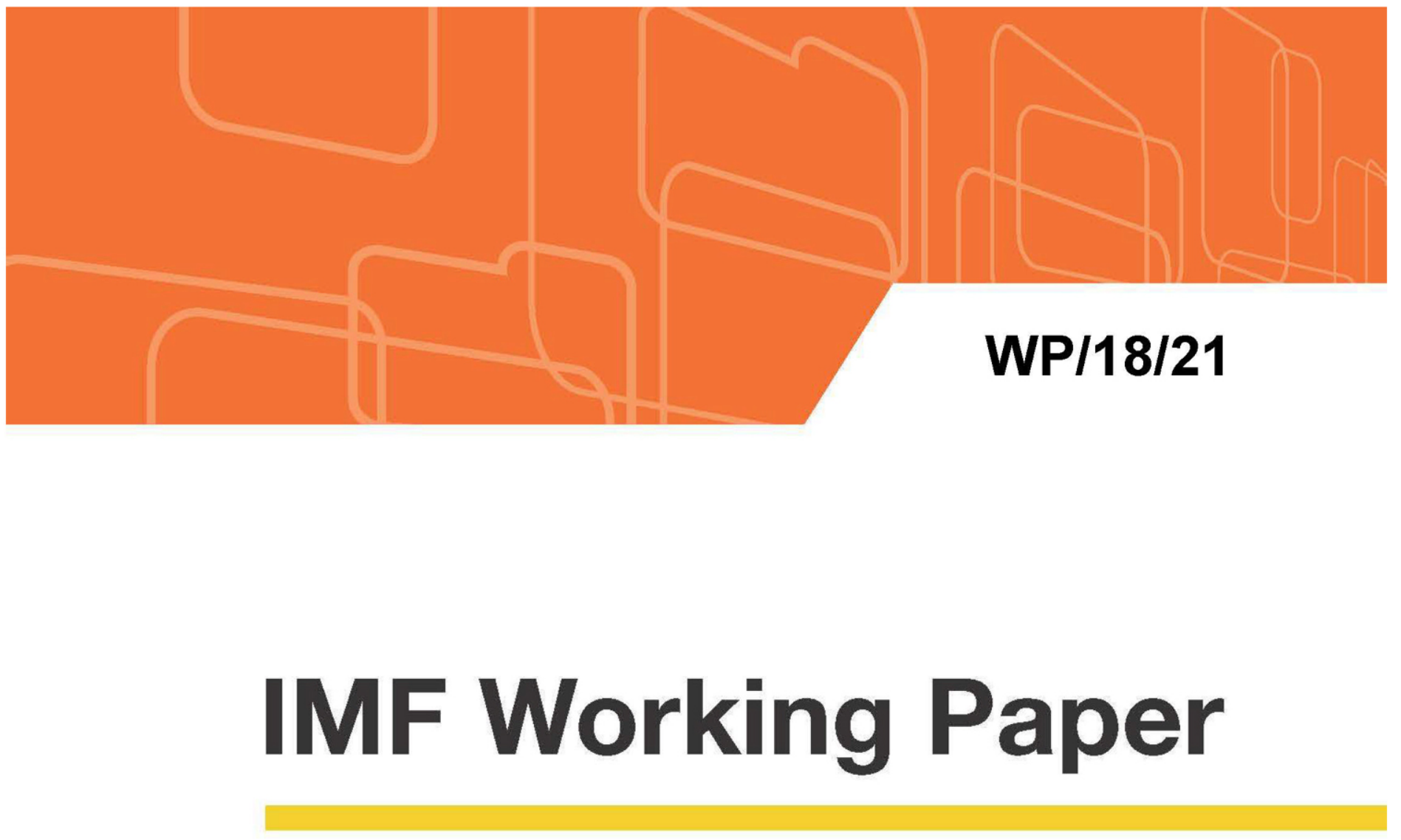

\title{
Euroization Drivers and Effective Policy Response An Application to the Case of Albania
}

\author{
by Guido della Valle, Vasilika Kota, Romain Veyrune,
}

Ezequiel Cabezon, and Shaoyu Guo

IMF Working Papers describe research in progress by the author(s) and are published to elicit comments and to encourage debate. The views expressed in IMF Working Papers are those of the author(s) and do not necessarily represent the views of the IMF, its Executive Board, or IMF management. 


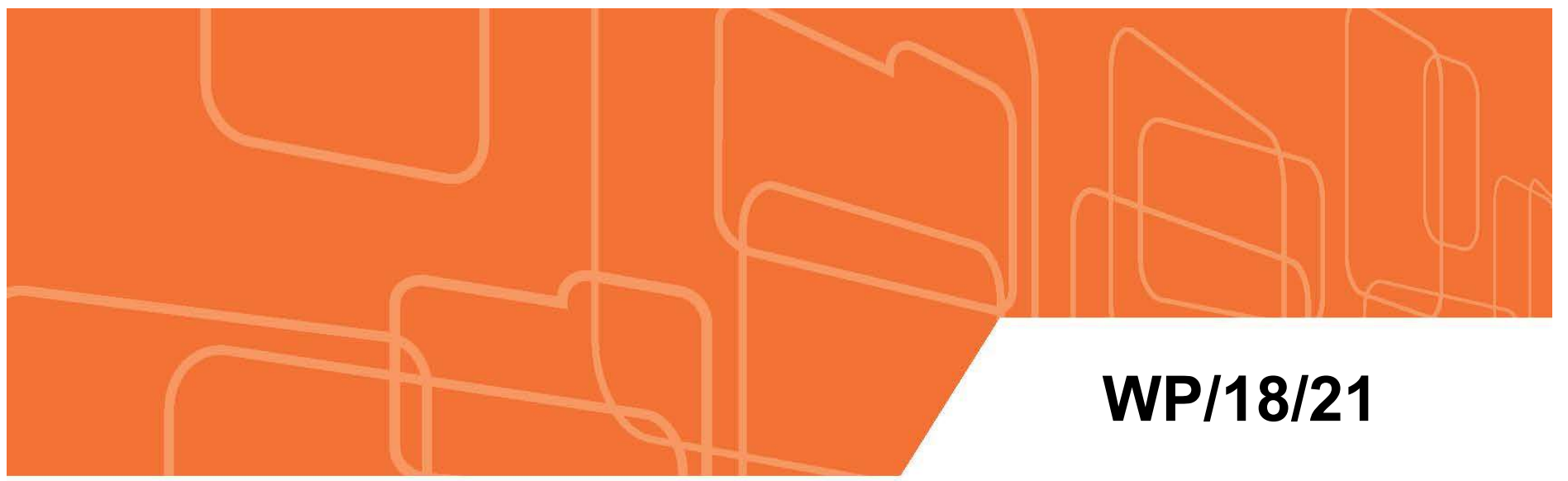

\title{
IMF Working Paper
}

\section{Euroization Drivers and Effective Policy Response An Application to the Case of Albania}

\author{
by Guido della Valle, Vasilika Kota, Romain Veyrune, \\ Ezequiel Cabezon, and Shaoyu Guo
}

IMF Working Papers describe research in progress by the author(s) and are published to elicit comments and to encourage debate. The views expressed in IMF Working Papers are those of the author(s) and do not necessarily represent the views of the IMF, its Executive Board, or IMF management. 


\title{
IMF Working Paper
}

\author{
Monetary and Capital Markets Department
}

\section{Euroization Drivers and Effective Policy Response: An Application to the case of Albania}

\section{Prepared by Guido della Valle, Vasilika Kota, Romain Veyrune, Ezequiel Cabezon, and Shaoyu Guo'}

Authorized for distribution by Simon Gray

January 2018

IMF Working Papers describe research in progress by the author(s) and are published to elicit comments and to encourage debate. The views expressed in IMF Working Papers are those of the author(s) and do not necessarily represent the views of the IMF, its Executive Board, or IMF management.

\begin{abstract}
This paper proposes a methodology to develop empirically based and theoretically consistent deeuroization policies. It is derived from the experience of Albania. The paper is the first attempt to provide an empirical measure of the optimal level of euroization. The results indicate that euroization is trending above the estimated measure in Albania, calling for deeuroization policies. In the long term, deeuroization requires maintaining the commitment to low and stable inflation in a context of greater exchange rate flexibility to encourage saving in local currency. In the short term, policies that mitigate the financial stability risk due to euroization contribute to deeuroization inasmuch as they make banking intermediation in euro less financially attractive to the public.

JEL Classification Numbers: E58 (Central Banks and Their Policies).
\end{abstract}

Keywords: euroization, dollarization, financial stability, and reserve requirement.

Authors’ E-Mail Addresses: gdellavalle@imf.org, rveyrune@imf.org, vkota@bankofalbania.org, ecabezon@imf.org, SGuo2@imf.org.

\footnotetext{
${ }^{1}$ The authors are grateful for helpful comments from Simon Gray, Steven Phillips, Anita Tuladhar, Mary Zephirin, and the participants of the conference "Negative Euro Area Interest Rates and Spillovers on Western Balkan Central Bank Policies and Instruments," Tirana, May 4-5, 2017.
} 


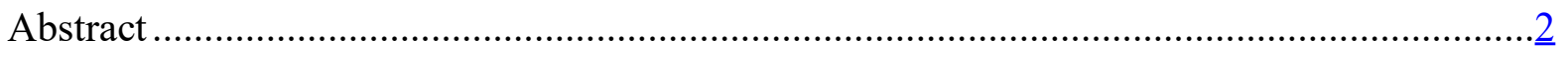

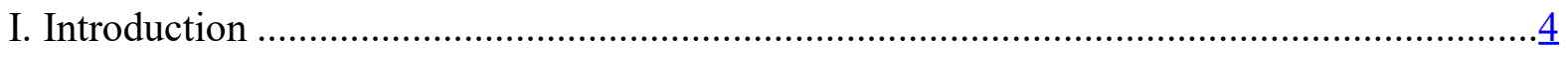

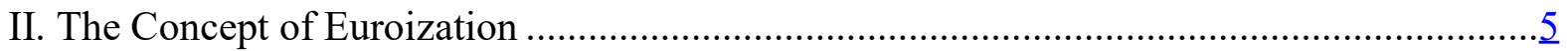

A. Review of the Economic Literature on Euroization.........................................

B. Measuring Euroization in Albania ...................................................................... 6

III. Euroization Drivers in Albania .................................................................................. 8

A. An Empirical Measure of the Optimal Euroization Level .....................................

B. Macroeconomic Euroization Drivers ............................................................

C. Mispricing of Foreign Exchange Risk .......................................................... 19

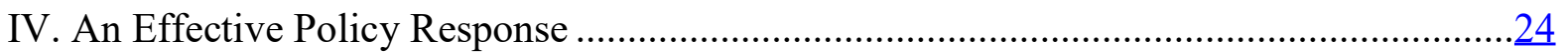

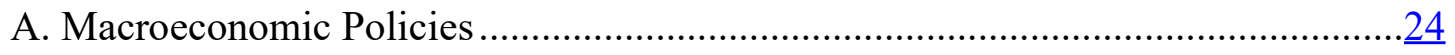

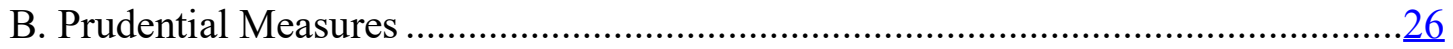

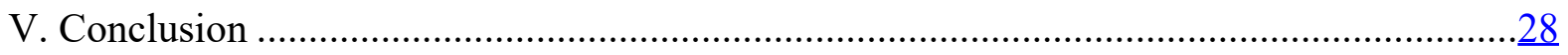

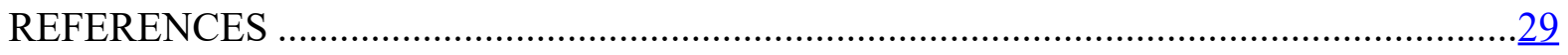

Figures

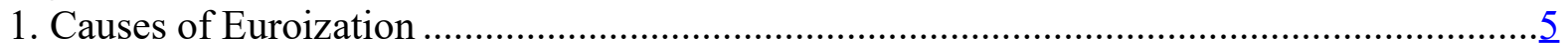

2. Evolution of Foreign Currency Deposits as a Share of Total Deposits .............................

3. Share of Foreign Currency Lending by Bank Ownership and New Credit Flow ................. $\underline{8}$

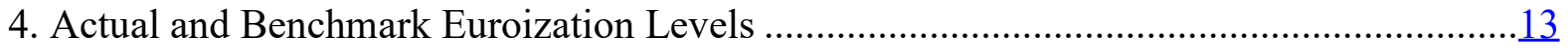

5. Two-way Risk in the Foreign Exchange Market ..........................................................14

6. Deposit Euroization and Interest Rate Differential—Time Series ................................15

7. Deposit Euroization and Interest Rate Differential—Correlation .....................................17

8. Deposit Euroization and Minimum Variance Portfolio ...................................................19

9. Risk Premia on Foreign Currency Loans and Exchange Rate Developments.....................20

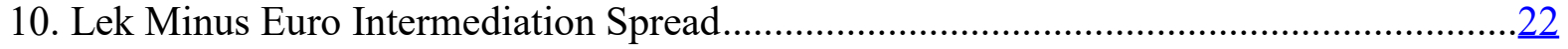

11. Structure of Banks' Sources of Foreign Currency Funding by Ownership ......................23

12. Causes of Euroization and Policy Responses ......................................................... 25

Tables

1. Results of the Panel Regressions ...............................................................................11

2. Interest Rate Spread as a Determinant of Financial Euroization ..................................16

3. Minimum Variance Portfolio and its Components in European Countries ........................18

Boxes

1. Estimates of the Seignoriage Losses Due to Euroization ............................................... 


\section{INTRODUCTION}

De facto financial euroization is high in Albania and has recently been increasing further. De facto dollarization or euroization occurs when the foreign currency is not the legal tender, but it partially replaces the domestic currency as a store of value, a unit of account, and a mean of payment. This paper uses the term euroization as the euro is the foreign currency used in Albania. It focuses on partial financial euroization, which happens when banks provide loans and take deposits in euro as well as in the local legal tender (e.g., the Albanian lek). As a result, more than half of banks' deposits are denominated in euros in Albania. Furthermore, financial euroization increased in recent years despite the track record of low inflation, which is a counterintuitive and puzzling development that we intend to address in the paper.

Euroization is a common phenomenon in several emerging economies. The optimal level of euroization for a small and open economy with strong economic links to the euro area is higher than zero, but lower than the levels observed in many candidate and potential candidate countries for European Union accession in the Western Balkans. High euroization entails lower seigniorage revenues, reduces the effectiveness of monetary policy, and heightens the vulnerability of the financial systems to exchange rate swings.

The objective of this paper is to provide a conceptual framework to identify and analyze euroization drivers with a view to inform the appropriate policy response. The framework has been developed in the context of the IMF technical assistance to Albania financed by the Swiss government. As a starting point, the paper proposes an empirical measure of the optimal level of euroization to serve as an indicative benchmark for deeuroization policies. Then, the paper aims at identifying the main euroization drivers at the different stages of the euroization process. Finally, the paper seeks to outline a comprehensive deeuroization strategy along several dimensions and a proper sequencing of actions. Its conclusions underpin the recently announced deeuroization strategy of the Albanian authorities.

Albania has an inflation targeting regime. The Bank of Albania (BoA) inflation objective has been set at 3 percent since the adoption of the framework in 2009. Since then, the BoA delivered stable and low inflation in line with its objective.

Sixteen banks operate in Albania although the 5 largest banks have a market share of approximately 80 percent. The market share of the two largest domestic banks increased rapidly as several subsidiaries of euro area banks, which once dominated the sector, deleveraged in the aftermath of the global financial crisis. Financial depth, measured as broad money to gross domestic product, is at 85 percent. It is boosted by remittances from the Albanian diaspora, which are often kept as euro-denominated deposits in local banks.

The paper is structured as follows: Section II summarizes the concept of euroization and assesses the recent euroization trends in Albania. Section III analyzes the drivers of euroization in Albania, including the optimal level of euroization. Section IV provides some suggestions on the policy responses to euroization in Albania, which may be equally applicable in other countries facing similar challenges and with similar characteristics. Section V is the conclusion. 


\section{The ConcePt OF Euroization}

\section{A. Review of the Economic Literature on Euroization}

This paper groups the causes of euroization into three categories. Starting from the optimal level of euroization (Phase 0 in Figure 1), euroization is the rational choice to protect wealth when the public has entrenched expectations of exchange rate depreciation due to macroeconomic instability (Phase 1); euroization is an insurance against tail risks, once macroeconomic stability has been achieved and the likelihood of a large exchange depreciation dropped significantly, but economic agents still seek protection from it due to the memories of past occurrences and the fear that instability may reoccur (Phase 2); and euroization is the result of the portfolio optimization choices from economic agents with a view to minimizing their portfolio variance when exchange rate volatility remains low compared with inflation volatility (Phase 3).

Figure 1. Causes of Euroization

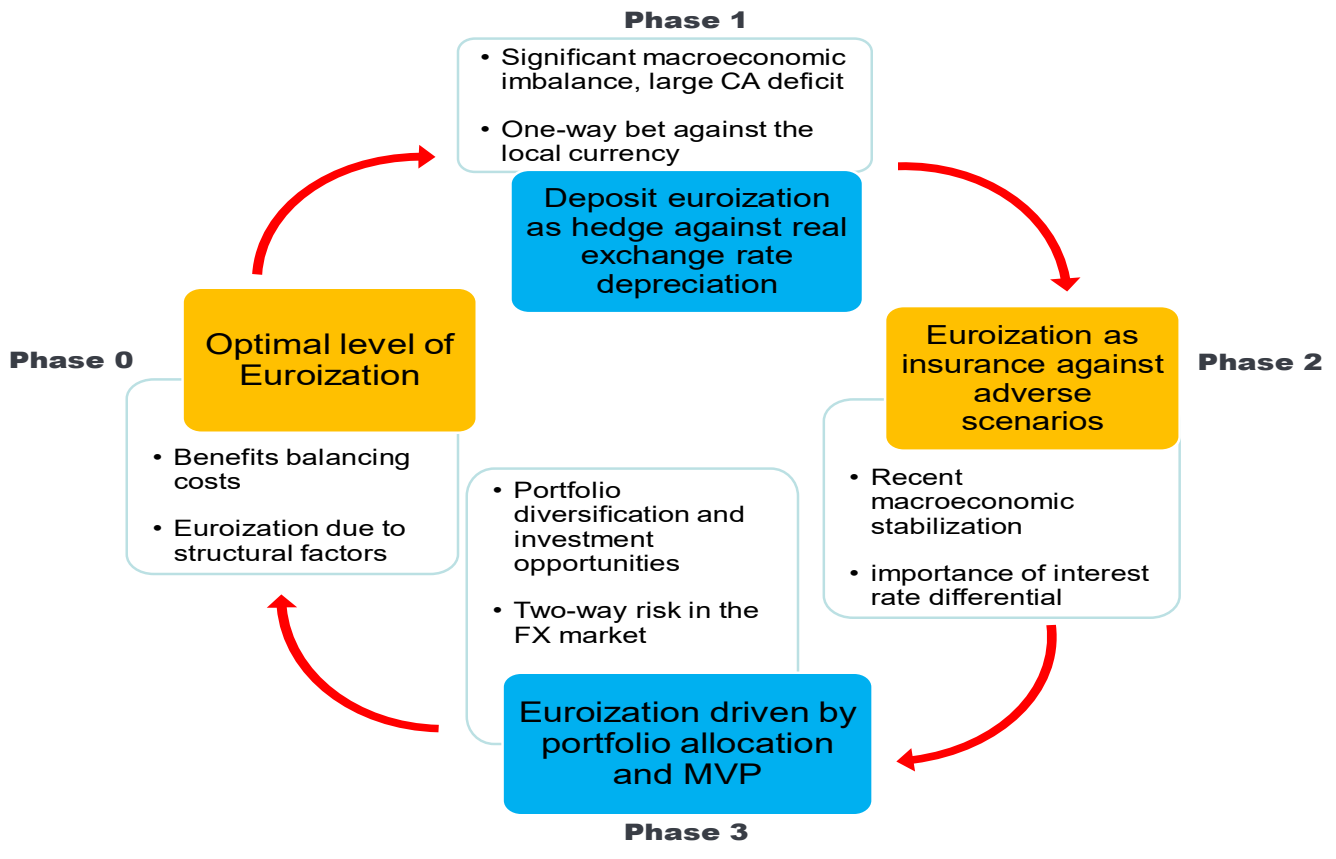

Source: authors.

Euroization usually starts as a one-way bet against the national currency due to unsound macroeconomic policies. Periods of acute macroeconomic instability and high inflation result in large exchange rate depreciation. Therefore, the public has one-way expectations regarding exchange rate developments and prefers to save in foreign currency as a hedge against the expected exchange rate depreciation. This reaction to unsound macroeconomic policies is the most frequent cause of euroization (Galindo and Leiderman, 2005; Herrera and Valdés, 2005; Kokenyne, Ley, and Veyrune, 2010; and Reinhart, Rogoff, and Savastano, 2003). On the lending side, euroization derives, in this phase, from the lack of funding in domestic currency due to the public preference to save in euro. 
Euroization usually outlasts the conditions that initially engendered it because of the insurance value attributed to euro deposits. The public keeps saving in euros even when the exchange rate starts moving in both direction and there are longer periods of exchange rate stability and appreciation. This is because the public perceives that euro deposits have an insurance value against possible, even if unlikely, large exchange rate depreciation (Feige and Dean, 2004; Uribe, 1997; and Weymouth, 2007). The memory of past crises tends to increase the insurance value of euro deposits as economic agents only gradually reassess the likelihood of the adverse scenarios. On the other hand, the mispricing of foreign currency deposits reduces the insurance costs in terms of foregone interest income when saving in foreign currency instead of local currency for the various reasons analyzed later in the paper.

As the insurance value of foreign currency deposits fades away, deposit euroization becomes motivated by portfolio optimization (Ize and Yeyati, 2003). As with other financial assets, the public is expected to allocate savings between foreign currency and local currency in a way that minimizes the variance of its investment portfolio for a given financial return, i.e., to choose the Minimum Variance Portfolio (MVP). Ize and Yeyati (2003) show that financial euroization displays high persistence whenever the expected volatility of inflation remains high in relation to that of the real exchange rate and when there is a high pass-through of exchange rate changes to the inflation rate as it is typically the case in small and open economies. Therefore, euroization may remain high even if macroeconomic stabilization is achieved; that is, inflation is low on average but remains volatile as the authorities also strive to stabilize the real exchange rate.

\section{B. Measuring Euroization in Albania}

There is evidence of currency substitution (Tase, 2005) for payment purposes in Albania. Domestic interbank payments in euros represent approximately 20 percent of total domestic interbank payments. Euro-denominated transfers represent on average 24 percent of the value of total banking system transfers for corporations and 39 percent of the value of total transfers for households. Ninety percent of euro transactions consist of wire transfers between individuals. There is also a widespread use of euros for cash transactions between banks and customers. Approximately 35 percent of cash transactions are denominated in euros, of which 40 percent are not related to placing deposits or paying loans but to direct payments between customers. These figures support the notion of a pervasive use of euro banknotes as a means of exchange, especially for larger value transactions.

Deposit euroization is rising in Albania despite the stable macroeconomic environment. In 2016, financial euroization-here defined as the ratio of foreign currency deposits to broad money-was 10 percentage points higher compared to 2006, while broad money also significantly increased (Figure 2). This trend is not only supported by currency inflows, but also by a pattern of a net positive demand from households since 2015 to convert domestic assets into foreign currency assets. This is taking place in conjunction with stable inflation and declining risk perception, considering the improvements in the macroeconomic outlook and debt sustainability. This paper will explore why euroization persisted (a phenomenon known as hysteresis) and even increased despite the good macroeconomic performances. 
Figure 2. Evolution of Foreign Currency Deposits as a Share of Total Deposits

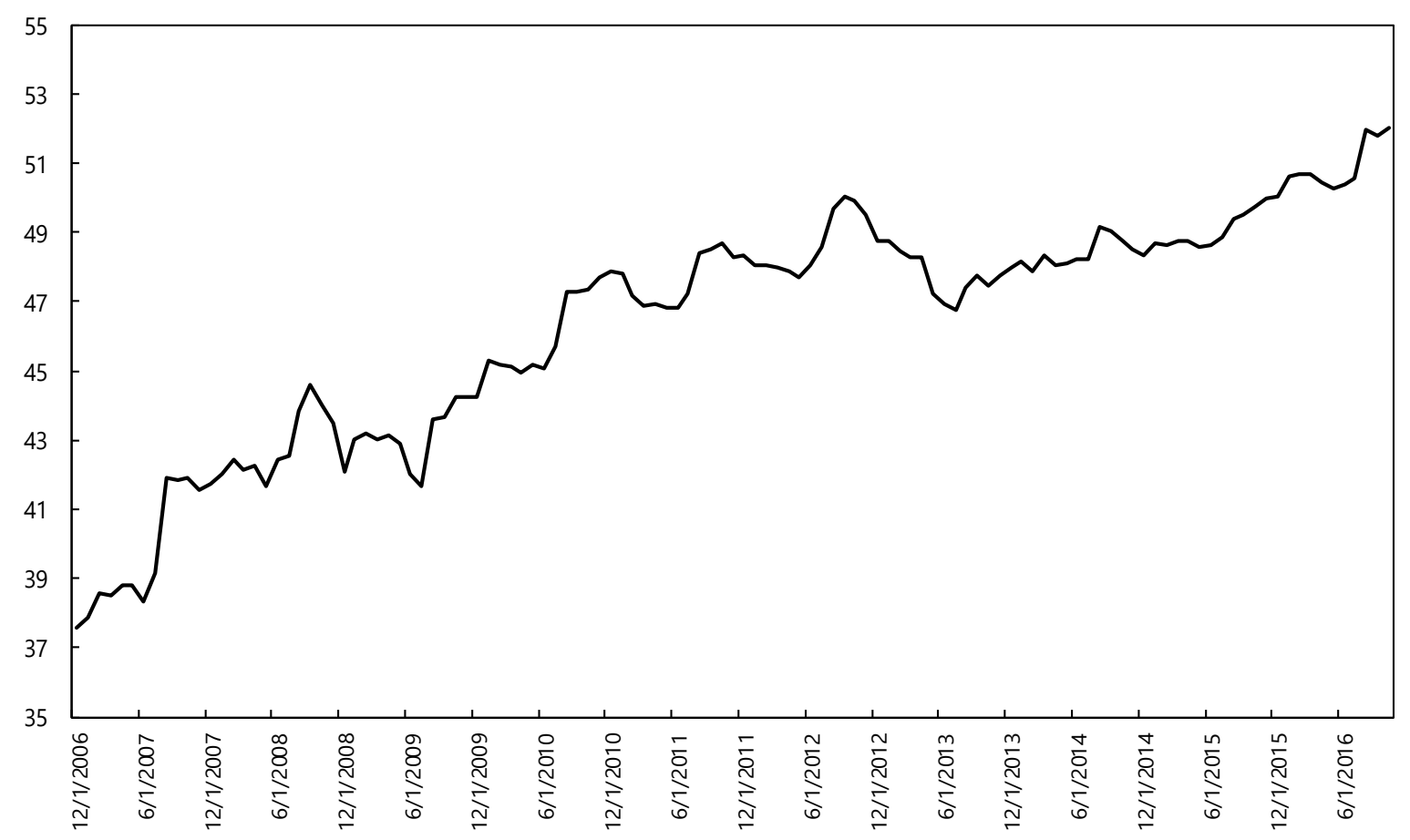

Source: BoA and authors.

Unlike deposit euroization, loan euroization has been decreasing. The share of foreign currency credit dropped to 60 percent of the total loan portfolio in 2016, compared to 70 percent in 2011 (Figure 3). During the same period, the share of foreign currency loans to unhedged borrowers declined even more markedly than the total share of foreign currency loans. Finally, for the first time since 2006 in 2016, new credit issued in local currency exceeded the amount of new credits denominated in foreign currency.

Writing off nonperforming loans contributed to reduce the stock of foreign currency loans. Since 2015, banks have been required to write off loans that have not performed for more than three years. Loans denominated in foreign currency accounted for 75 percent of these loans. Banks have written off about 4 percent of the credit portfolio in domestic currency and 7 percent of the credit portfolio in foreign currency, thereby reducing the outstanding amount of loans denominated in foreign currency compared with lek-denominated loans.

Finally, banks have been increasing their lending to nonresidents to balance their net open positions. Investments abroad as a share of total assets increased from 10 percent in 2008 to 28 percent in 2016 because of sluggish domestic demand for loans in foreign currency and limited alternative investment opportunities in foreign currency in the domestic market. Therefore, banks replaced foreign currency loans to local borrowers with loans to nonresidents to keep balanced net open positions. These developments provide new challenges and new risks, stemming from the exposure to nonresidents operating in different jurisdictions. 
Figure 3. Share of Foreign Currency Lending by Bank Ownership and New Credit Flow; 12-month Moving Average
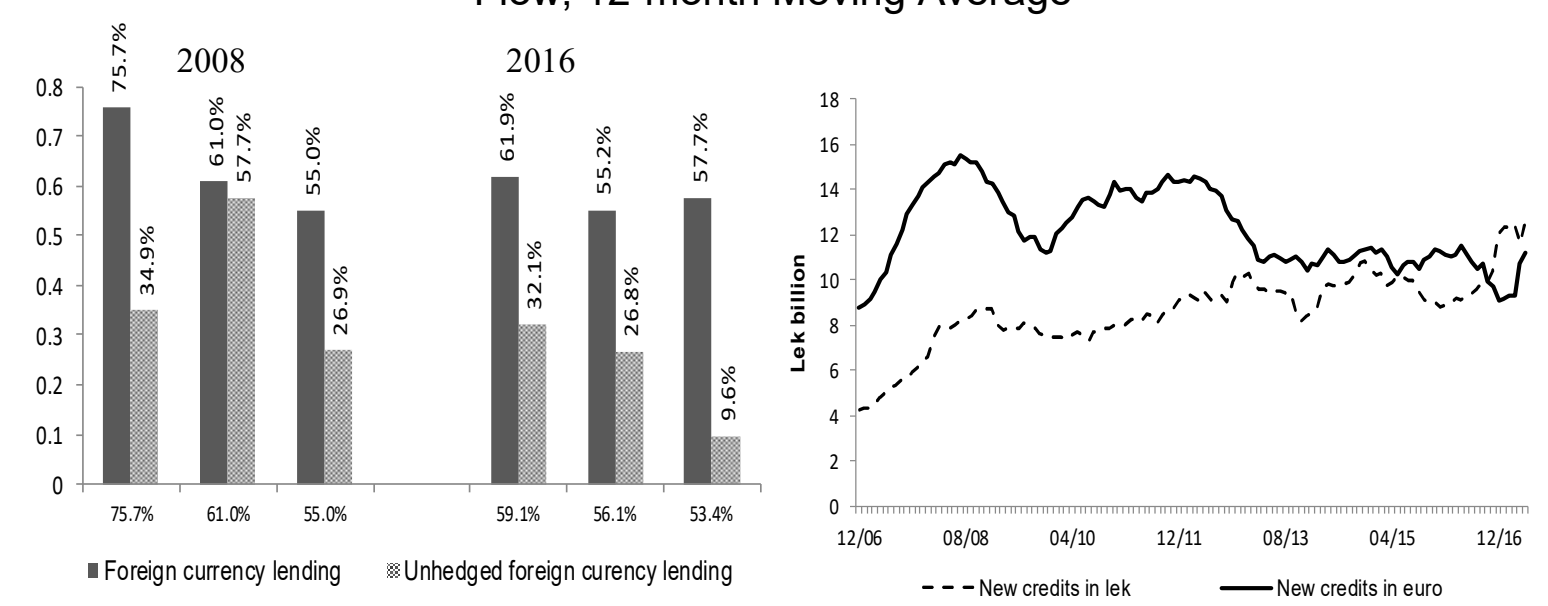

Source: BoA and authors.

Source: BoA and authors.

\section{Euroization Drivers in Albania}

\section{A. An Empirical Measure of the Optimal Euroization Level}

Conceptually, there is an optimal euroization level, below which the costs of deeuroization measures outweigh the benefits. The costs of euroization include losses of seigniorage, which amount to 0.6 percent of GDP each year in Albania (see estimates in Box 1), impairment of monetary policy transmission, and financial stability risk due to unhedged exchange rate exposure in the economy and the absence of a lender of last resort in foreign currency.

On the other hand, financial euroization supports financial sector deepening. Measures to mitigate intermediation in foreign currency make such intermediation more expensive, go against public preferences, hinder access to attractive funding sources, and deprive investors of portfolio diversification opportunities. Disincentives to intermediation in foreign currency may not lead to a proportional increase in local currency intermediation, resulting in some disintermediation or slowdown in financial deepening.

In practice, the optimal level of euroization cannot be directly measured. Besides the seigniorage loss, which can be quantified (Box 1), we cannot directly measure the other euroization costs and its benefits.

This paper, thus, proposes an empirical estimate as a measure of the optimal euroization level. It is based on a panel analysis (hereafter "benchmark euroization") assuming that euroization would not deviate from its optimal level on average over time and across regions. The benchmark euroization indicates the level of euroization that an economy is expected to experience given its structural characteristics while controlling for its record of macroeconomic performances. The difference between the actual euroization level and the benchmark provides an indication of the potential scope of deeuroization policies. 


\section{Box 1. Estimates of the Seignoriage Losses due to Euroization}

Euroization represents a loss of seigniorage income for the central bank. Seigniorage revenue is the difference between the value of money and the cost to produce it. Bogetic (2000) proposes two measures of seigniorage: either as the one-time cost of the stock of foreign currency in circulation; or as a continuous flow cost in terms of seigniorage income foregone related to the annual change in the stock of foreign banknote in circulation. Given the nature of euroization in Albania- that it is not a conscious official choice - the calculation of the seigniorage loss using the flow method is more appropriate.

The seigniorage loss is estimated from the perspective of the central bank balance sheet. The use of foreign banknotes reduces the use of local currency banknotes, which represents a liquidity absorbing autonomous factor. Therefore, ceteris paribus, the banking system liquidity deficit is less than it would be without euroization. This reduces the banking system refinancing needs and the potential size of the domestic financial asset portfolio with an opportunity cost equal to the average return on these assets minus the banknotes' production cost.

Estimates of seigniorage losses amount to at least lek 6 billion per annum. Using the data on monetary euroization of customer payments, we estimate that foreign currency banknotes in circulation represent approximately 35 percent of the total currency in circulation (as in Section II.B). This leads to an estimate of the equivalent of lek 172 billion in circulation. Considering an average refinancing rate throughout the business cycle of around 3.5 percent, and ignoring the negligible production costs of banknotes, this represents an average opportunity cost of lek 6 billion or 0.4 percent of GDP. The actual cost could, however, be higher considering that the average return on the BoA's portfolio of domestic financial assets is higher than the refinancing rate.

In addition, the significant share of euro deposits obliges the central bank to keep more foreign currency reserves to address the possible need for emergency liquidity assistance in foreign currency. In turn, higher foreign currency reserves reduce the banking system's refinancing needs and the possible size of the portfolio of domestic financial assets. If the foreign currency reserves held by BoA were in line with the average level suggested by the reserve adequacy matrix of the IMF (IMF, 2016), the BoA would avoid an opportunity cost estimated at approximately lek 3 billion based on the difference between the BoA's average refinancing rate throughout the business cycle and the average return on foreign currency reserves.

Lower central bank profits entail lower distributions from the central bank to the Ministry of Finance. Total costs for Albania have been estimated at lek 9 billion, approximately 0.6 percent of the GDP per annum. Lower profits are also a possible threat to central bank independence (Bini Smaghi, 2007).

We estimate the euroization benchmark based on a worldwide panel data analysis of countries covering the period 2000-2015. As in most of the empirical literature (Feige and Dean, 2004; Ize and Levy-Yeyati, 2003; and Kokenyne, Ley, and Veyrune, 2010), the explained variable of the model is the share of foreign currency deposits in broad money as data on deposits are available for more countries than those on loans. The regression includes two sets of explanatory variables: (i) structural variables, reflecting country characteristics over which policy makers have limited control; and (ii) policy variables, reflecting macroeconomic performances during and before the period under study. Each set of explanatory variables is explained in more details below.

The benchmark is the share of foreign currency deposits in broad money predicted by the model with a special treatment for policy variables. Predicted foreign currency deposits in broad money are computed based on the regression estimators and the actual values of the 
structural variables for each country. On the other hand, the contribution of policy variables is estimated based on the regression estimators as before, but the actual values of the policy variables for each country are replaced with values reflecting a track record of good macroeconomic performances. This method consists in "neutralizing" policy variables, which is tantamount to a scenario in which each country maintained low inflation and exchange rate flexibility in the period considered, thereby creating a counterfactual narrative for the effect of actual policies on euroization.

The structural variables are drawn from the literature on the choice of exchange rate arrangements. Mundell (1961) and McKinnon (1963) set criteria that determine whether an independent monetary policy would benefit a given country. The factors that encourage relinquishing an independent monetary policy also support full or partial euroization, including the flexibility of local prices to adjust to external shocks and the synchronization of economic cycles with the anchor currency. This nominal flexibility is expected to be better achieved in small and open economies with high capital and labor mobility.

The euroization determinants, reflecting the criteria in the literature on the choice of exchange rate arrangements, include variables such as economic size (population and real GDP per capita), the degree of trade openness (export and import as a percentage of GDP), and capital account openness. Capital account restrictions are estimated based on the Financial Account Restrictiveness Index prepared by the IMF, which is based on the capital controls reported in the Annual Report on Exchange Rate Arrangements and Exchange Restrictions. Remittances as a percentage of GDP control for labor mobility. A dummy variable is introduced to control for euroization versus dollarization.

Policy variables include the MVP, exchange rate volatility, and inflation, including lagged inflation to test for the impact of high inflation memory on euroization. These variables are introduced to avoid an estimation bias due to omitted variables and to determine a policy neutral counterfactual. Inflation is set low at 1 percent. MVP is set equal to zero. Finally, exchange rate volatility, which is defined as the difference between the minimum and the maximum exchange rate of the domestic currency against the reference currency over one year, is assumed to be 3.5 percent. This is in line with the average of free-floating exchange rate regimes.

We tested several specifications as robustness checks. Specification 1 in Table 1 presents the results of the regression, including only structural variables. It can be compared with specifications 2 to 4 , which include policy variables, to assess the impact of past policies on the euroization level. In Albania, structural variables explain most of euroization, but past policies also contribute (significantly) to explain it. Specification 2 includes MVP, whereas specifications 3 and 4 include inflation and exchange rate volatility, but not MVP. This last variable, in fact, is a combination of inflation and exchange rate volatility, creating a risk of multiple collinearities. 


\section{Table 1. Results of the Panel Regressions}

\begin{tabular}{|c|c|c|c|c|}
\hline $\begin{array}{l}\text { Dependent variable: } \\
\text { Foreign currency deposits/total deposits }\end{array}$ & (1) & (2) & (3) & (4) \\
\hline \multicolumn{5}{|l|}{ OCA variables } \\
\hline Log population & $\begin{array}{c}-2.427 * * * \\
(0.557)\end{array}$ & $\begin{array}{c}-2.471 * * * \\
(-4.252)\end{array}$ & $\begin{array}{c}-2.105^{* * *} \\
(-3.583)\end{array}$ & $\begin{array}{c}-2.732 * * * \\
(-4.089)\end{array}$ \\
\hline Log real GDP per capita & $\begin{array}{c}-9.299 * * * \\
(0.795)\end{array}$ & $\begin{array}{c}-9.701 * * * \\
(-11.17)\end{array}$ & $\begin{array}{c}-8.080 * * * \\
(-8.382)\end{array}$ & $\begin{array}{c}-6.567 * * * \\
(-6.718)\end{array}$ \\
\hline Trade openness & $\begin{array}{c}0.0411 \\
(0.0251)\end{array}$ & $\begin{array}{c}0.0612 * * \\
(2.366)\end{array}$ & $\begin{array}{c}0.0711^{* *} \\
(2.574)\end{array}$ & $\begin{array}{c}0.0872 * * * \\
(2.881)\end{array}$ \\
\hline Remittances as share of GDP & $\begin{array}{c}0.245^{* *} \\
(0.111)\end{array}$ & $\begin{array}{c}0.180 \\
(1.595)\end{array}$ & $\begin{array}{c}0.226^{* *} \\
(2.107)\end{array}$ & $\begin{array}{c}0.350 * * * \\
(3.286)\end{array}$ \\
\hline $\begin{array}{l}\text { Financial Account } \\
\text { Restrictiveness Index }\end{array}$ & $\begin{array}{c}-28.83 * * * \\
(2.929)\end{array}$ & $\begin{array}{c}-30.13 * * * \\
(-10.08)\end{array}$ & $\begin{array}{c}-31.61 * * * \\
(-10.59)\end{array}$ & $\begin{array}{c}-24.11 * * * \\
(-7.144)\end{array}$ \\
\hline \multicolumn{5}{|l|}{ Policy variables } \\
\hline Minimum variance portfolio & & $\begin{array}{c}0.119 * * * \\
(3.034)\end{array}$ & $\begin{array}{l}0.0571 \\
(1.447)\end{array}$ & $\begin{array}{c}-0.00604 \\
(-0.151)\end{array}$ \\
\hline $\log$ variation coefficient $=\mathrm{L}$ & & & $\begin{array}{c}-3.005^{* * *} \\
(-4.687)\end{array}$ & $\begin{array}{c}-3.537 * * * \\
(-5.049)\end{array}$ \\
\hline Inflation $=\mathrm{L}$, & & & $\begin{array}{c}1.625 * * * \\
(4.749)\end{array}$ & $\begin{array}{c}1.958 * * * \\
(5.425)\end{array}$ \\
\hline Inflation $=\mathrm{L} 1$, & & & & $\begin{array}{c}0.104^{* * *} \\
(3.866)\end{array}$ \\
\hline \multicolumn{5}{|l|}{ Binary variable } \\
\hline Europe & $\begin{array}{c}14.19 * * * \\
(1.550)\end{array}$ & $\begin{array}{c}12.69 * * * \\
(7.888)\end{array}$ & $\begin{array}{c}10.96 * * * \\
(6.854)\end{array}$ & $\begin{array}{c}8.027 * * * \\
(4.538)\end{array}$ \\
\hline Constant & $\begin{array}{c}152.1 * * * \\
(11.82)\end{array}$ & $\begin{array}{c}153.0 * * * \\
(11.62)\end{array}$ & $\begin{array}{c}133.7 * * * \\
(9.546)\end{array}$ & $\begin{array}{c}123.6^{* * *} \\
(8.646)\end{array}$ \\
\hline Observations & 1,313 & 1,246 & 1,111 & 947 \\
\hline R-squared & 0.322 & 0.333 & 0.373 & 0.404 \\
\hline Year FE & Yes & Yes & Yes & Yes \\
\hline
\end{tabular}

Source: BoA, International Financial Statistics (IFS), and authors' estimates.

Note: Robust $p$-values in parentheses. Columns 1-4 estimated with ordinary least squares.

${ }^{* * *} p<0.01,{ }^{* *} p<0.05,{ }^{*} p<0.1$.

The results are consistent with the original assumptions. They point to a high benchmark euroization level in Albania. Small and open economies, such as Albania, tend to be more euroized. Albania has one of the most open capital accounts in the sample, a condition that 
increases its level of financial euroization. Remittances, which amount to a high share of GDP in Albania, lift the euroization benchmark. In addition, financially developed markets (that is, typically those with higher GDP per capita) tend to have lower euroization.

Countries in the European Union, as well as countries like Albania, which are candidates for European Union membership, tend to have a higher level of euro deposits as a percentage of total deposits than the rest of the world. This can be largely explained by the convergence process with the euro area and the perspective of euro adoption in the future.

Policy variables have the impacts predicted by the literature. The euroization level predicted by the criterion on the choice of exchange rate arrangements and the policy variables is close to the actual euroization level. As expected, the MVP is an important determinant of deposit euroization. Inflation and lagged inflation both increase deposit euroization.

Albania's level of euroization is drifting away from its benchmark level. Albania's euroization level is just about 10 percent above the level predicted by the model, if Albania had the average euroization level as justified by the structural features of its economy and by strong macroeconomic performances. This result places Albania in the category of BosniaHerzegovina, Bulgaria, and Macedonia, for which euroization is close to the benchmark value predicted by the model. However, the level of euroization in Albania is increasing and, thus, diverging from its empirical benchmark, calling for measures to stop and reverse the deposit euroization trend. 
Figure 4. Actual and Benchmark Euroization Levels

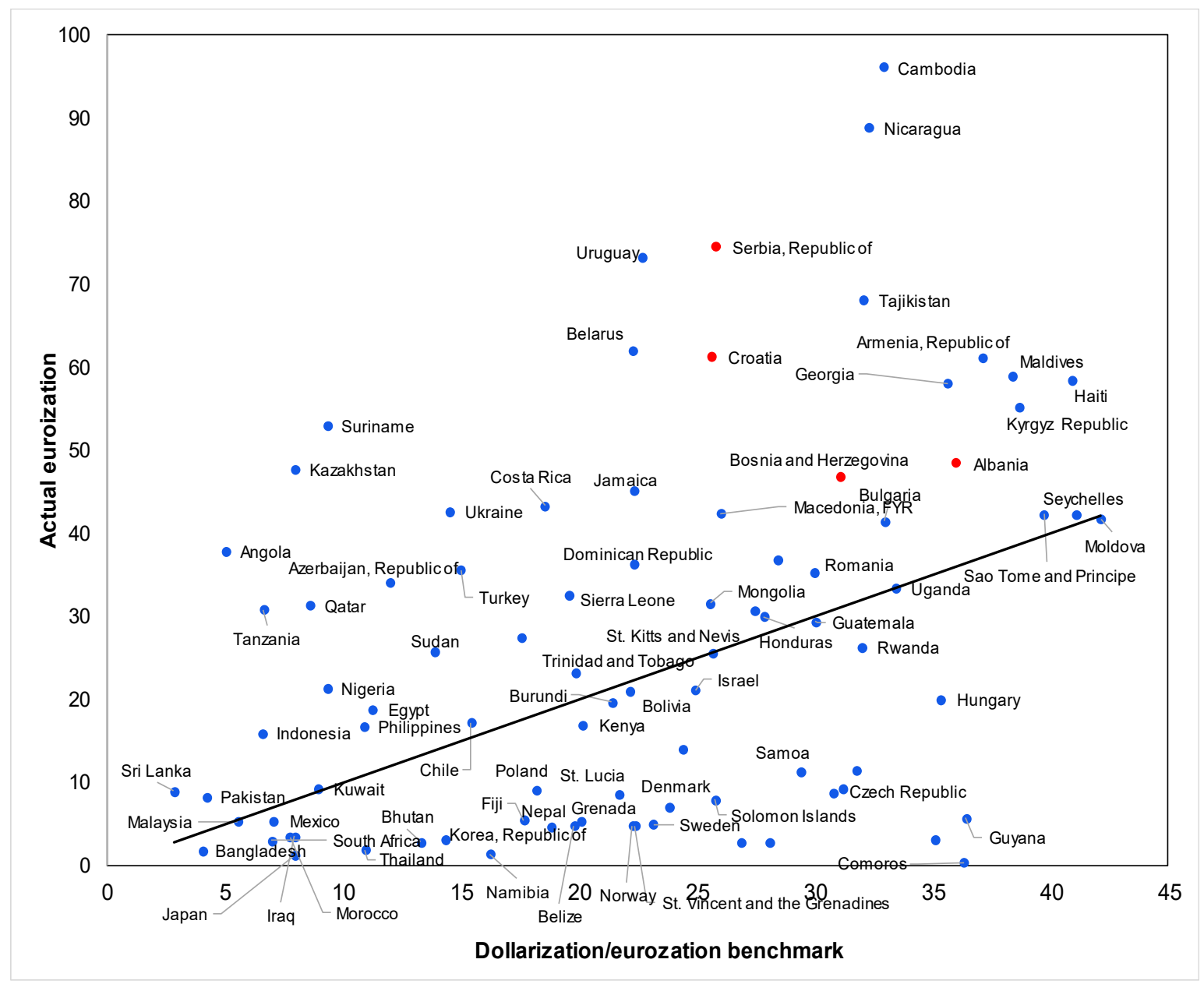

Source: IFS and authors.

Note: Dollarization/euroization benchmark is the adjusted predicted values of specification 4.

\section{B. Macroeconomic Euroization Drivers}

The payoff of one-way bets against the lek declined dramatically during the last six years in Albania (Figure 5) thanks to macroeconomic stabilization and the subsequent exchange rate stability. Since 2014, odds of an exchange rate appreciation on any day during the next 250 working days have remained close to one. This means that the exchange rate had as many chances to appreciate as to depreciate during this period, thereby reflecting two-way risk in the market. Recently, the payoff of betting against the lek even turned negative, as the lek experienced - since the end of 2015 - its longest episode of slow but consistent appreciation vis-à-vis the euro in more than 10 years.

The latest "Euro Survey" conducted by the National Bank of Austria in Central, Eastern, and Southeastern European countries confirmed that Albanian households, like most households in the region, continue to show greater confidence toward the euro than in the national 
currency. This derives from the high inflation and the rapidly depreciating exchange rate in the 1990s, which undermined the public confidence in the local currencies.

Figure 5. Two-Way Risk in the Foreign Exchange Market

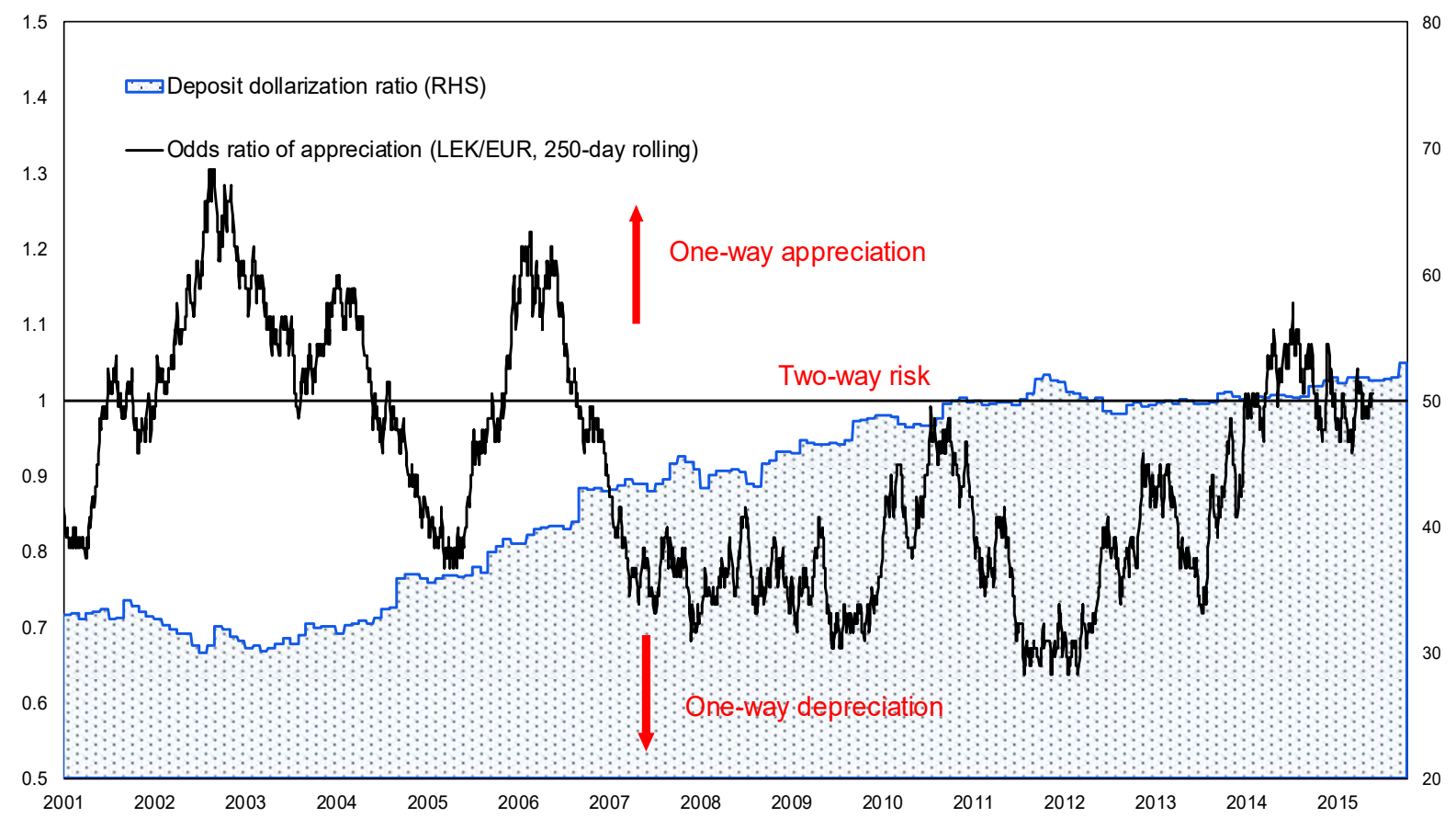

Source: BoA and authors.

The survey, however, shows that the confidence in the lek relative to the euro has increased in the past seven years. This suggests that the higher demand for foreign currency deposits during the past few years is not driven by an erosion of the confidence in the lek. Albanian public confidence towards banks has been steadily increasing and is higher than in neighbouring countries, thereby indicating that the preference towards euros is not driven by a fundamental mistrust towards the banking system. Improved confidence in banks could have been, in fact, a factor behind deposit euroization as savings in large euro banknotes are transferred into the banking system. The persistence of a relative high preference for cash (in euros as well as in leks) is underpinned by the high levels of informality in Albania.

The interest rate differential is an important driver of deposit euroization, at least in the short term. Public demand for foreign currency deposits, like other forms of insurance, is a function of the insurance premium, expressed in terms of the interest rate differential between domestic and foreign currency assets, and of the perceived likelihood of adverse scenarios. Considering that memory of crises, i.e., the adverse scenario against which insurance is sought, fades away only slowly, the variable that can exert influence in the short term is the insurance cost. The insurance cost is the interest rate differential representing the extra return foregone when insurance is sought via deposits in foreign currency. In this regard, the interest rate differential has declined since 2013, thereby reducing the premium paid by lek deposits over foreign currency deposits (Figure 6). 
Figure 6. Deposit Euroization and Interest Rate Differential-Time Series

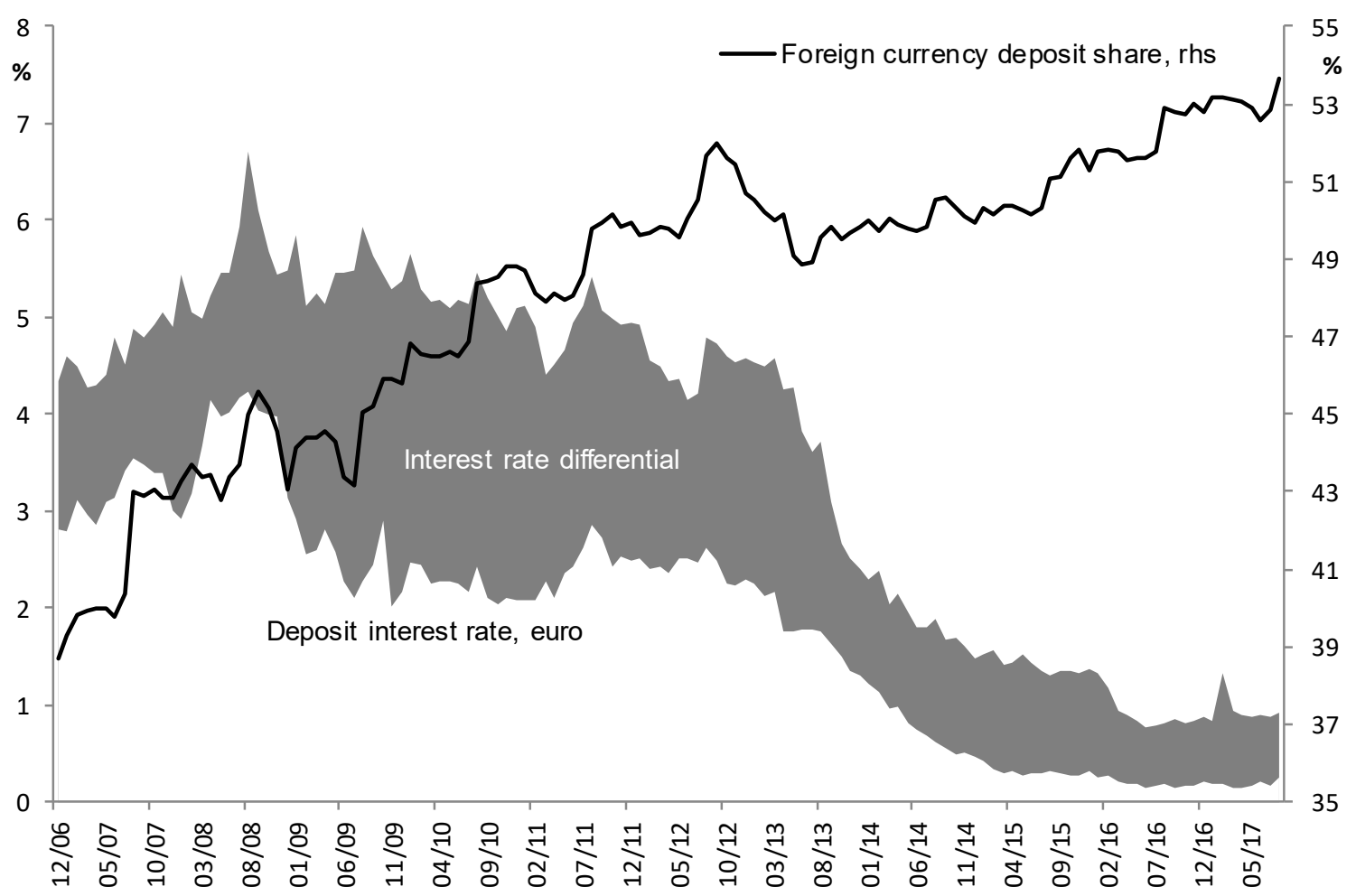

Source: BoA and authors.

An increase of 1.0 percentage point in the spread between BoA and ECB monetary policy rates reduces the share of foreign currency deposits by about 0.9 percentage points during 2003-16 per the estimates in Table 2. Different specifications are presented in Table 2 as robustness checks. The main results are (1) that there is a negative and significant relationship between the monetary policy spreads and euroization, independently from the chosen specifications and estimation periods; and (2) that other variables, such as expected depreciation (E(depreciation) in Table 2), expected inflation (E(inflation)), and sovereign spread are positively correlated to an increase in euroization.

The interest rate differential is an explanatory variable of the currency composition of new deposit flows. Figure 7 shows a negative relationship between new euro deposits and the interest spread once controlled for the other explanatory variables previously presented. This applies to the spread between policy rates as well as to the spread between euro and lek deposit rates in the Albania banking sector. The negative relationship could be found throughout the period except during brief crisis-related episodes of heightened risk aversion, in which higher interest rate differentials were barely enough to offset the greater preference towards assets denominated in foreign currency as a hedge against the risk of negative economic developments. While the interest rate differential still influences euroization, its impact seems to have, however, decreased during the last five years. 
Table 2. Interest Rate Spread as a Determinant of Financial Euroization

\begin{tabular}{|c|c|c|c|c|c|c|}
\hline Dependent variable: & (1) & (2) & (3) & (4) & (5) & (6) \\
\hline $\begin{array}{c}\text { Foreign currency } \\
\text { deposits/total deposits }\end{array}$ & $2003-16$ & $2007-16$ & $2010-16$ & $2010-16$ & $2010-16$ & $2010-16$ \\
\hline \multirow[t]{2}{*}{ Spread of policy rates } & $-0.943 * * *$ & $-0.777 * *$ & $-0.569^{*}$ & & $-0.376^{*}$ & \\
\hline & $(0.000)$ & $(0.017)$ & $(0.096)$ & & $(0.091)$ & \\
\hline \multirow[t]{2}{*}{ Spread of banking rates } & & & & -0.457 & & -0.233 \\
\hline & & & & $(0.165)$ & & $(0.291)$ \\
\hline \multirow[t]{2}{*}{ E(Depreciation) } & & & 0.121 & 0.141 & 0.075 & 0.113 \\
\hline & & & $(0.179)$ & $(0.101)$ & $(0.371)$ & $(0.142)$ \\
\hline \multirow[t]{2}{*}{$\mathrm{E}$ (Inflation) } & & & $0.382 *$ & $0.523 * *$ & 0.200 & 0.344 \\
\hline & & & $(0.078)$ & $(0.018)$ & $(0.265)$ & $(0.132)$ \\
\hline \multirow[t]{2}{*}{ Sovereign spread } & & & 0.001 & 0.001 & $0.001 * * *$ & $0.001 * *$ \\
\hline & & & $(0.240)$ & $(0.312)$ & $(0.008)$ & $(0.036)$ \\
\hline \multirow[t]{2}{*}{ Minimum variance portfolio } & 1.314 & 2.268 & 1.170 & 0.723 & 0.184 & 0.004 \\
\hline & $(0.514)$ & $(0.312)$ & $(0.514)$ & $(0.673)$ & $(0.733)$ & $(0.995)$ \\
\hline \multirow[t]{2}{*}{ Depreciation } & 0.000 & 0.003 & & & & \\
\hline & $(0.997)$ & $(0.968)$ & & & & \\
\hline \multirow[t]{2}{*}{ Inflation } & -0.061 & -0.005 & & & & \\
\hline & $(0.506)$ & $(0.968)$ & & & & \\
\hline \multirow{2}{*}{$\begin{array}{l}\text { Lagged foreign currency to } \\
\text { Lek deposit ratio }\end{array}$} & & & & & $0.734 * * *$ & $0.787 * * *$ \\
\hline & & & & & $(0.000)$ & $(0.000)$ \\
\hline \multirow[t]{2}{*}{ Constant } & $45.211 * * *$ & $48.661 * * *$ & $47.942 * * *$ & $47.089 * * *$ & $12.650 * * *$ & $9.328 * * *$ \\
\hline & $(0.000)$ & $(0.000)$ & $(0.000)$ & $(0.000)$ & $(0.000)$ & $(0.000)$ \\
\hline Observations & 159 & 111 & 66 & 66 & 66 & 66 \\
\hline R-squared & 0.208 & 0.823 & 0.971 & 0.967 & 0.844 & 0.839 \\
\hline
\end{tabular}

Source: BoA, IFS, and authors' estimates.

Note: The estimations are based on a single equation model including key variables detailed in the literature (Ize and Levy Yeyati, 2003; De Nicolo, Honohan, and Ize, 2005; and several IMF working papers). The analysis is based on monthly information for the period of January 2003 to March 2016. Robust p-values in parentheses. Columns 1-4 estimated using Cochrane Orcutt correction for error autocorrelation. Columns 5-6 estimated with ordinary least squares as we include the lag of the dependent variable.

${ }^{* * *} p<0.01,{ }^{* *} p<0.05,{ }^{*} p<0.1$.

Rigidity of the nominal remuneration rate at the zero lower bound is an important factor explaining the lower interest rate differential in the past couple of years. Even though euro short-term wholesale funding costs are negative in the euro area, banks in Albania have had little scope to lower their remuneration rates below the zero floor, as they rely almost exclusively on customer deposits to which they cannot charge negative remuneration because of the risk of cash hoarding and large-scale disintermediation. By contrast, the pass-through 
of lower BoA policy rates to lek deposit rates has been high, thereby resulting in narrower deposit interest rate differentials.

Figure 7. Deposit Euroization and Interest Rate Differential—Correlation
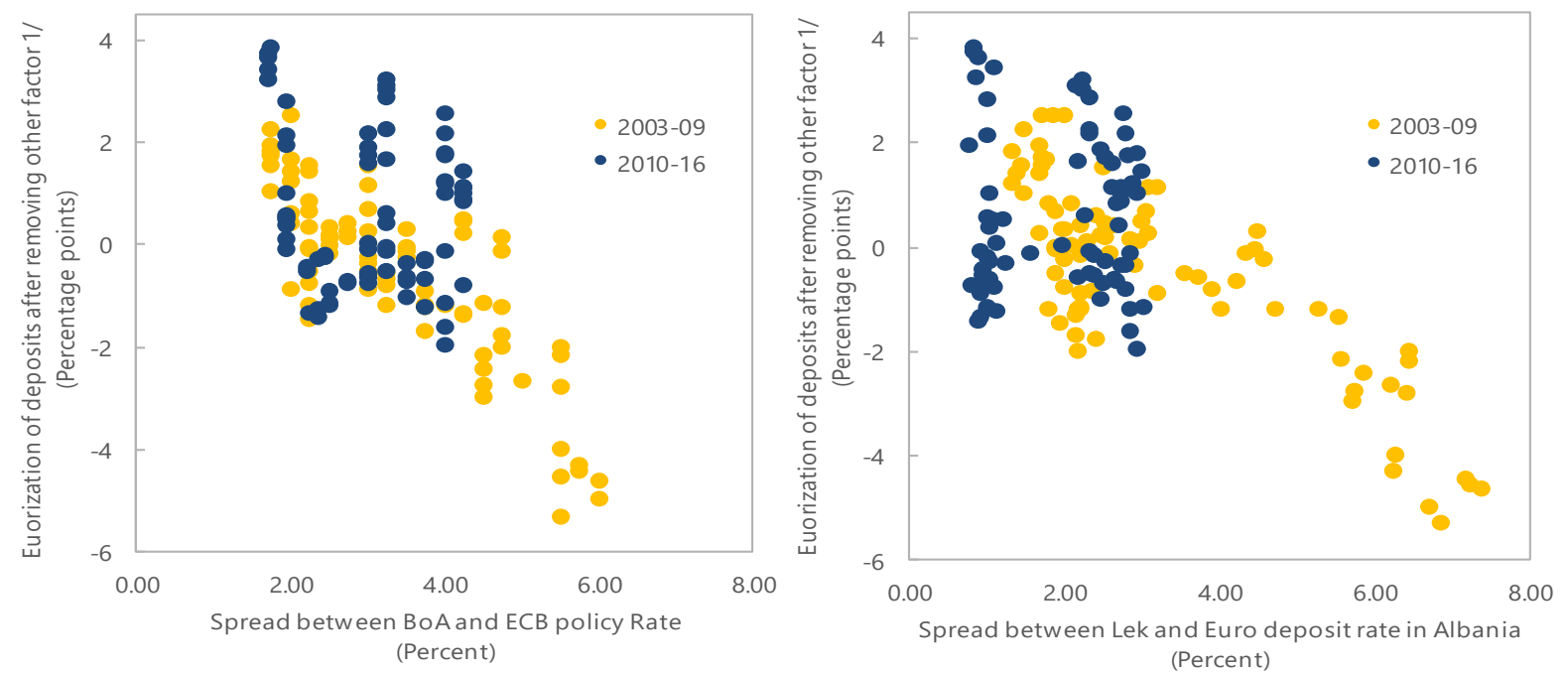

Source: BoA and authors.

1/ Regression residual of the ratio foreign currency to total deposit on inflation, openness, and MVP.

The last part of this section is dedicated to the MVP as a determinant in the public decision whether to allocate savings between local and foreign currencies. Following Ize and Yeyati (2003), we computed the MVP for non-euro area countries in Europe, as well as Israel and Turkey, which have different monetary policy frameworks, exchange rate arrangements, and levels of market development, such as follows:

$\lambda^{*}=S_{\pi \pi}+S_{s s}+2 \pi S_{\pi s}$

$\lambda^{*}:$ MVP dollarization ratio

$S_{\pi \pi}:$ Variance of inflation

$S_{s s}:$ Variance of real exchange rate

$S_{\pi s}:$ Covariance between inflation and real exchange rate

The MVP is higher in Albania than in any other countries in the sample (Table 3). The MVP is positively correlated with inflation volatility and negatively correlated with the real exchange rate volatility. Inflation volatility is higher in Albania than in the other inflation targeters, while inflation is not significantly higher on average. In addition, real exchange rate volatility is closer to that experienced in fixed exchange rate arrangements than the one prevailing in floating exchange rate arrangements. Finally, the covariance between inflation 
and the real exchange rate is among the highest in the panel due to the small and open nature of the Albanian economy.

Table 3. Minimum Variance Portfolio and its Components in European Countries

\begin{tabular}{lcccccc}
\hline Countries (2009-2016) & Deposit dollarization & $\lambda^{*}$ & $S_{\pi \pi}$ & $S_{S S}$ & $S_{\pi s}$ & Exchange rate arrangements \\
\hline Albania & 41.7 & 47.1 & 0.70 & 0.87 & 0.55 & Floating \\
Bosnia and Herzegovina & 49.9 & 40.6 & 0.21 & 0.43 & 0.19 & Currency board \\
Bulgaria & 47.7 & 32.7 & 0.23 & 0.76 & 0.22 & Currency board \\
Croatia & 62.1 & 34.7 & 0.27 & 0.71 & 0.29 & Crawl-like \\
Czech Republic & 10.5 & 11.6 & 0.14 & 2.13 & 0.06 & Stabilized \\
Denmark & 6.8 & 24.0 & 0.14 & 0.52 & 0.00 & Conventional peg \\
Hungary & 18.9 & 5.7 & 0.22 & 4.28 & 0.08 & Floating \\
Iceland & 8.8 & 11.0 & 0.23 & 4.85 & -0.01 & Floating \\
Israel & 21.1 & 10.1 & 0.15 & 1.48 & 0.01 & Floating \\
Macedonia & 48.7 & 35.1 & 0.30 & 0.54 & 0.25 & Stabilized \\
Moldova & 45.6 & 19.4 & 0.55 & 3.26 & 0.16 & Floating \\
Norway & 3.7 & 19.1 & 0.18 & 1.77 & 0.16 & Free floating \\
Poland & 12.1 & 4.1 & 0.09 & 4.25 & -0.01 & Free floating \\
Romania & 38.4 & 18.7 & 0.29 & 2.22 & 0.30 & Floating \\
Serbia & 69.9 & 29.4 & 0.51 & 2.40 & 0.59 & Floating \\
Sweden & 5.5 & 6.8 & 0.14 & 2.07 & -0.01 & Free floating \\
Turkey & 36.3 & 12.6 & 0.66 & 5.10 & 0.17 & Floating \\
\hline
\end{tabular}

Source: IFS and authors.

Euroization in Albania reflects well its MVP. Figure 8 shows a positive and larger-than-one correlation coefficient between MVP and deposit euroization among European countries. Therefore, most countries in the sample are more euroized than predicted by the MVP, except for the most advanced economies, which suggests that MVP is not the only factor driving euroization in these countries. On the other hand, while Albania has the highest MVP, its euroization level is, in fact, slightly lower than what precited by the MVP.

The results underscore the challenge of reducing euroization in a small and open economy. The structurally high exchange rate pass-through tends to increase the weight given to exchange rate considerations in relation to the inflation target in monetary policy decisions, which, thus, keeps the MVP relatively high. This persistently high MVP encourages savings in foreign currency and, thus, financial euroization. 
Figure 8. Deposit Euroization and Minimum Variance Portfolio

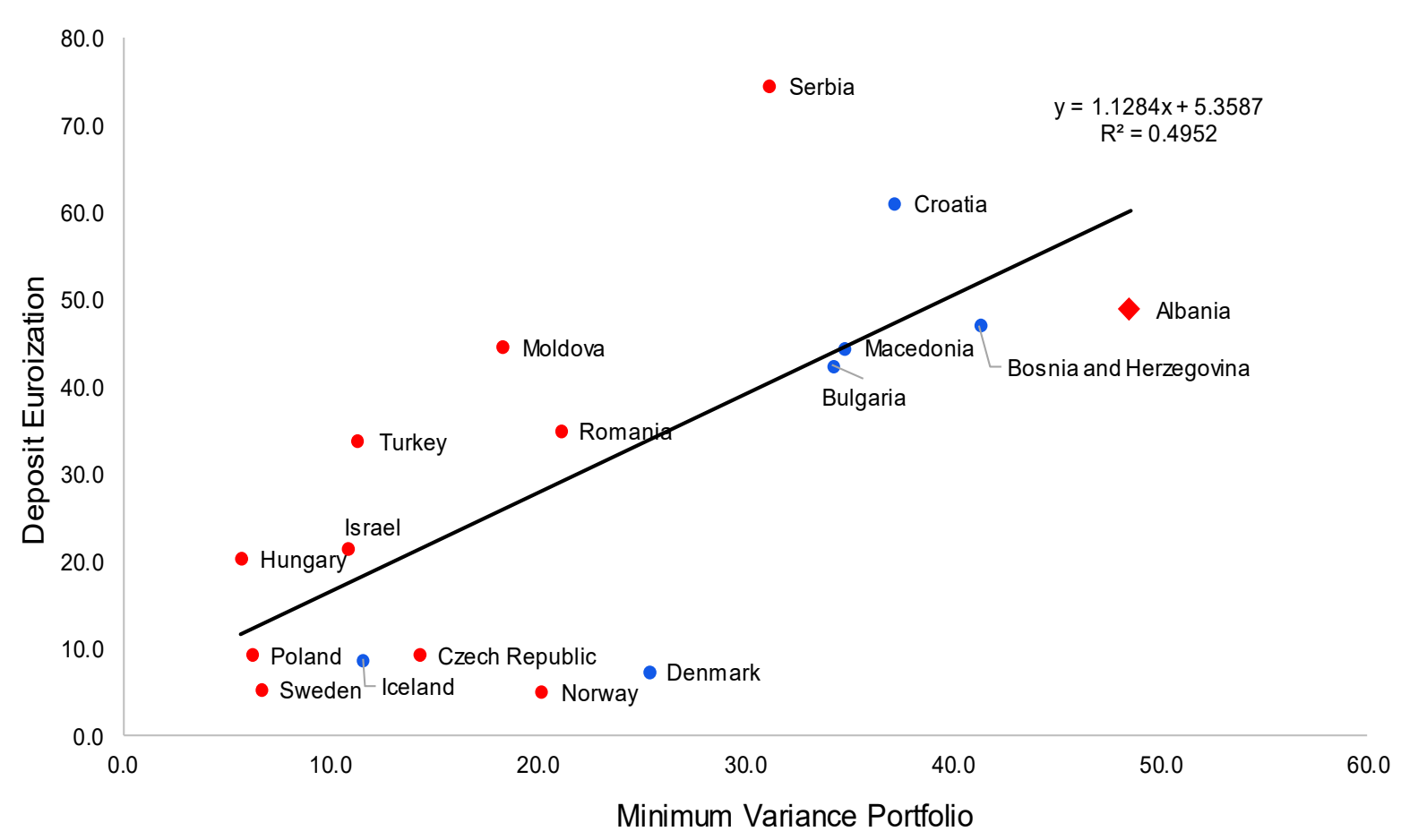

Source: BoA and authors.

\section{Mispricing of Foreign Exchange Risk}

This section tests several possible euroization drivers related to the risk-return profile of foreign currency assets and liabilities vis-à-vis those denominated in domestic currency. The demand for loans in foreign currency can be shaped by two factors: (1) borrowers ignore or underestimate the exchange rate risk; and (2) borrowers are subject to moral hazard and externalities.

Underestimation of exchange rate risk could arise when borrowers frontload current consumption at a risk of lower future consumption if a material and persistent exchange rate depreciation occurs. With low levels of financial literacy, economic agents may also suffer from partial money illusion. Debt servicing costs, as well as income creditworthiness analysis, may justify higher credit in foreign currency with its lower interest payments if large exchange rate depreciation scenarios are not factored in. The systematic underestimation of the exchange rate risk cannot be explained if economic agents make rational decisions. However, several factors, which are described below, can explain such apparent irrationality.

Moral hazard refers to the expectations of debt relief in case of large exchange rate depreciation (Beckmann, 2017). The term externalities, here, refers to a situation in which the total exchange rate exposure of individuals aggravates the depth of the crisis, which is not considered by individual borrowers when they make their borrowing decisions. In this sense, borrowing in foreign currency can be a rational choice for individuals if they assume that 
they could benefit from the lower interest rate on borrowing in foreign currency while exchange rate losses, if they materialized, would be "socialized."

Past large exchange rate depreciation episodes have been associated with higher domestic interest rates. Ex-ante stress test analysis based on historical data thus tends to compensate the exchange rate risk on loans in foreign currency with the exposure to interest rate risk on domestic loans, which are almost exclusively based on variable interest rates. It is, therefore, not obvious which of the two risks will prevail. Ex post, in light of vulnerabilities to adverse exchange rate swings, central banks may be induced to react to exchange rate depreciation pressures by increasing the policy interest rate, thus corroborating the ex-ante assessment.

Backward-looking credit risk policy of banks contributes to the mispricing of the exchange rate risk. Figure 9 shows the cyclical component of the risk premia on foreign currency loans (i.e., the difference between actual intermediation spread and its long-term equilibrium) and the real exchange rate gap (i.e., the deviation of the real exchange rate from its long-term equilibrium value). It appears that the real exchange rate gap leads the risk premia on foreign currency loans. This means that banks adapt the risk premia to exchange rate development rather than basing them on forward-looking expectations of exchange rate developments and estimates of an equilibrium exchange rate towards which the actual exchange rate should converge in the medium to long term.

Figure 9. Risk Premia on Foreign Currency Loans and Exchange Rate Developments

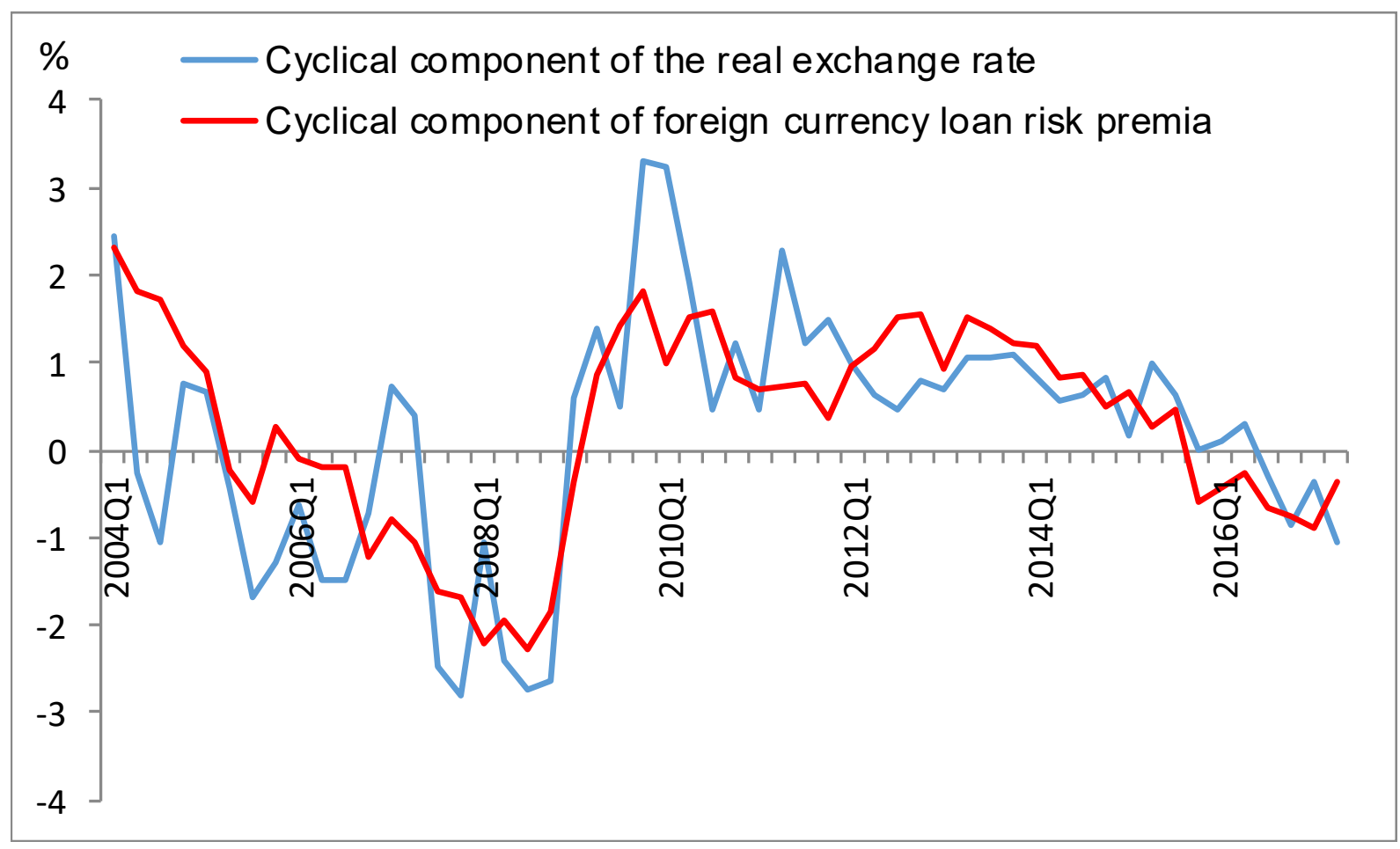

Source: BoA and authors. 
The BoA's surveys of lending practices confirm that banks do not discriminate against unhedged loans in foreign currency. A 2016 survey of the six largest banks (65 percent of the sector assets) carried out by the BoA showed that banks have no special policy regarding unhedged loans in foreign currency, despite the higher risk weights of foreign currency loans to unhedged borrowers imposed by BoA (unhedged loans in foreign currency have a 150 percent risk weight according to BoA's regulation). The creditworthiness assessment follows the same procedures and applies the same quantitative and qualitative criteria for both domestic and foreign currency loans. Banks do not run direct sensitivity analysis of the impact of exchange rate depreciation on borrowers' capacity to repay the debt.

Banks do not apply significantly differentiated quantitative or qualitative criteria in their risk assessments of domestic and foreign currency-denominated loans. For businesses, the average solvency ratio, calculated as the ratio of net cash flow to annual credit instalments, stands at a minimum level of 1.2-1.4, with no difference made between domestic currency loans and unhedged foreign currency loans. Sensitivity analysis run by the banks, which indirectly includes the exchange rate risk in the form of higher import prices or higher credit costs, allows for the fluctuation of this ratio to an average level of 1-1.2. For households, debt service ratios stand on average at about 30-35 percent, while loan-to-value limits for property lending stands at 70-80 percent, with no differentiation for lending in foreign currency, let alone unhedged foreign currency lending.

Banks provide limited guidance to potential borrowers on exchange rate risk. Banks' sensitivity analyses on exchange rate depreciation are not generally shared with potential borrowers and do not lead to higher solvency ratios for businesses more exposed to exchange rate risks. Moreover, banks have not undertaken any contingency analysis that considers a possible double shock on debt instalments brought about by a severe depreciation coupled with an increase in the foreign interest rate. For households, sensitivity analysis of the direct risk of exchange rate depreciation on borrower's solvency is lacking.

Euro area monetary policy spillovers supported financial intermediation in euro. The interest rate differential between loans in domestic currency and foreign currency has a significant role in fostering lending in foreign currency in Albania. Despite a large decrease in lek loans' interest rates during the last 10 years, loans in foreign currency remain cheaper than loans in domestic currency as the average rate for new euro loans in 2016 was 4.8 percent compared with 7.2 percent for new lek loans. The euro loans' interest rate indexation to EURIBOR rates, which dipped into negative territory, is the main reason for their continuous decline. This happens despite the longer average maturity of lending in foreign currency (53 months on average as opposed to 46 months for domestic lending), which should increase the credit risk of foreign currency loans, and despite the higher credit risk of lending in foreign currency to unhedged borrowers.

The intermediation spread (i.e., the difference between loan and deposit rates) is higher in leks than in euros. Therefore, it is financially more advantageous for banks' customers to save and borrow in euros rather than in leks. The spread was in secular decline due to a faster 
decrease in lek loan rates than in lek deposit rates relative to the same decreases in euro loan and deposit rates (Figure 10).

After the introduction of the negative rate in the euro area, the trend in intermediation spreads was reversed. This is because the euro intermediation spread compressed as domestic euro deposit rates reached the zero lower bound while the euro loan rates, indexed on EURIBOR, continued decreasing. On the other hand, lower domestic policy rates were passed through seamlessly to both lek deposits and loans.

\section{Figure 10. Lek Minus Euro Intermediation Spread}

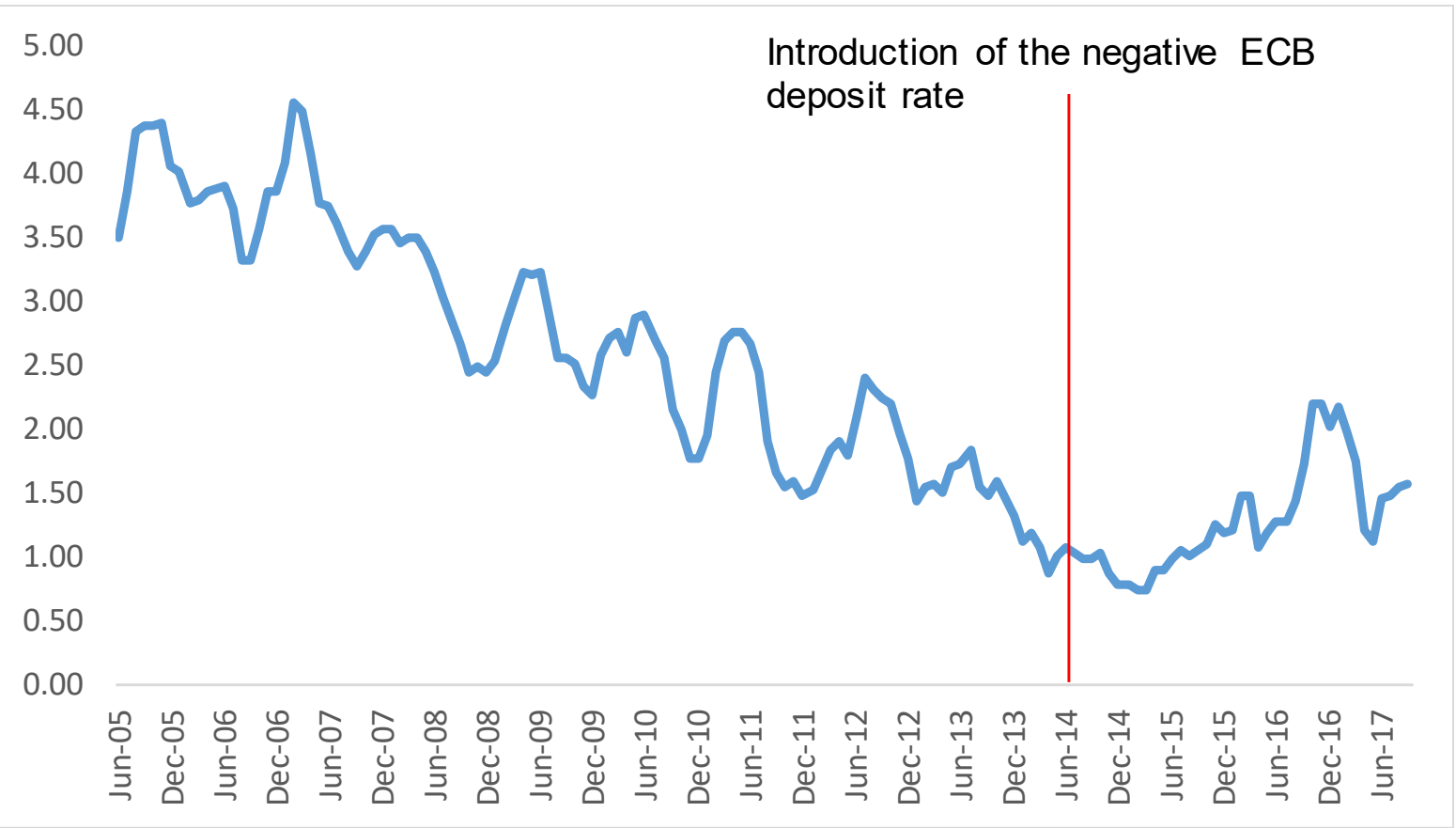

Source: BoA and authors.

Relative access to, and costs of, different funding sources could also contribute to euroization (Basso, Calvo-Gonzalez, and Jurgilas, 2007). An abundant, cheap, and elastic supply of euro deposits - underpinned by a steady flow of remittances-encourages banks to provide eurodenominated loans, minimizing currency mismatches on their balance sheets. This is especially the case when the return on domestic loans denominated in foreign currency beats investment in the euro area money market.

Foreign banks also have an inherent bias toward foreign currency intermediation. Beside the abundant and ready supply of euro funding, the denomination of the banks' capital in foreign currency may fuel this bias, as foreign currency intermediation exposes the interest rate margin to lower volatility when converted to the reporting currency, in which dividends are paid.

The large presence of foreign-owned banks had some role in the euroization of banks' balance sheets in the past. Foreign banks have remunerated foreign currency deposits at a 
higher rate to make it easier to substitute funding from parent banks and from the international wholesale market, in general, with local funding. This substitution effort followed the stigmatization of the reliance on wholesale funding from abroad and from the parent bank by the European Systemic Risk Board (ESRB/2011/1). Banks could have reduced the rate on foreign currency deposits if they had not needed to replace parent banks' foreign currency funding with local foreign currency funding. For euro area banks operating in Albania, funding sources have shifted toward a greater reliance on foreign currency deposits and lower reliance on credit lines from the parent banks, as shown in Figure 11.

Figure 11. Structure of Banks' Sources of Foreign Currency Funding by Ownership

(in percent)

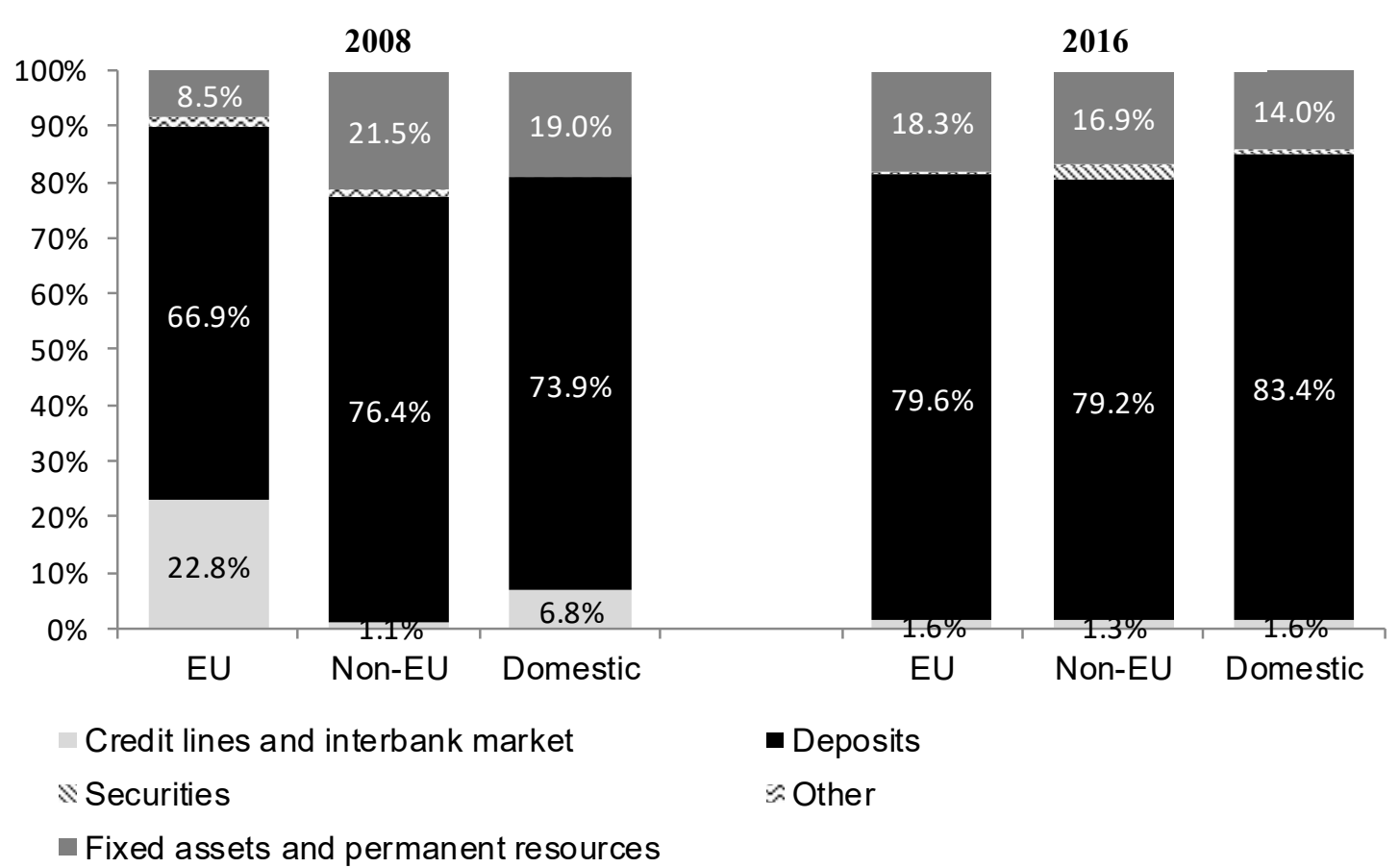

Source: BoA and authors.

On the deposit side, banks tend to underprice the liquidity risk entailed by foreign currency deposits. Foreign currency deposits have a greater liquidity risk as the central bank is limited in its ability to act as lender of last resort. This risk could be partially offset by the public preference to save in foreign currency, which makes funding in foreign currency more stable for the banks than domestic currency funding. However, lek funding appears at least as stable as funding in foreign currency because more than half of household deposits are denominated in leks and 60 percent of corporate deposits, which are usually less stable than household deposits, are denominated in foreign currency.

Deposits in foreign currency benefit from an implicit favorable regulatory treatment in Albania. Similar reserve requirements and prudential liquidity ratios were applied in Albania to foreign currency and domestic currency deposits until recently, so that banks did not bear the full costs of their foreign currency intermediation. The costs are partially transferred to 
the authorities, which were until recently remunerating the reserve requirement in foreign currency at zero. This is a rate higher than the short-term rates in the euro area financial market and higher than the remuneration the BoA could achieve on the investment of the funds received as reserve requirements.

The BoA changed the remuneration policy of required reserves in foreign currency in September 2016. The remuneration rate of required reserves in foreign currency was aligned with the ECB deposit facility rate, effectively reducing it by 0.4 percent. This remuneration policy change halted the implicit subsidization of foreign currency deposits. Since the change was introduced, the intermediation spread narrowed by more than 0.50 percent in favor of domestic currency intermediation (Figure 10) although the latter remains wider than the foreign currency intermediation spread by approximately 1.70 percent.

Albania's deposit insurance scheme covers both foreign currency and domestic currency deposits to the same extent, for the same maximum amount. Besides, the pay-out on foreign currency deposits takes place in foreign currency. This supports foreign currency deposits as the value of the guarantee provided is greater on these deposits in the event of a large exchange rate depreciation associated with a banking crisis. In fact, even though the amount insure is the same ex-ante, domestic deposits would require, in case of an exchange rate depreciation, lower payouts than the domestic currency equivalent of the foreign currency deposit amount insured. Providing the guarantee in foreign currency may also entail costly accumulation of foreign currency reserves.

\section{An Effective Policy Response}

\section{A. Macroeconomic Policies}

The first, initial, challenge for macroeconomic policy is to reduce the perception that foreign currency deposits are a good hedge against exchange rate risk. This requires fighting entrenched exchange rate depreciation expectations through the preservation of sound and sustainable macroeconomic policies, fiscal discipline, and credible institutions. In practice, it often involves fiscal consolidation and the temporary stabilization of the exchange rate to remove one-way bets against the domestic currency, thereby moving the system from phase 1 to phase 2 of the euroization cycle described in Figure 12.

The second challenge for macroeconomic policy is to rein in the insurance value of foreign currency deposits. In this phase, the central banks strive to build up their reputation as effective inflation targeters, which can deliver stable and low inflation over time. However, the fear of floating remains high because of the presence of important unhedged exposures to the exchange rate risk in the economy. Therefore, central banks usually maintain a minimum remuneration premium on local currency deposits compared to the foreign currency deposits to impose an opportunity cost on those that decide to save in foreign currency as an insurance against tail risks. The minimum remuneration premium is also aimed at preventing the conversion of domestic currency in foreign currency deposits that could destabilize the exchange rate. This corresponds to the phase 2 of the euroization cycle. 


\section{Figure 12. Causes of Euroization and Policy Responses}

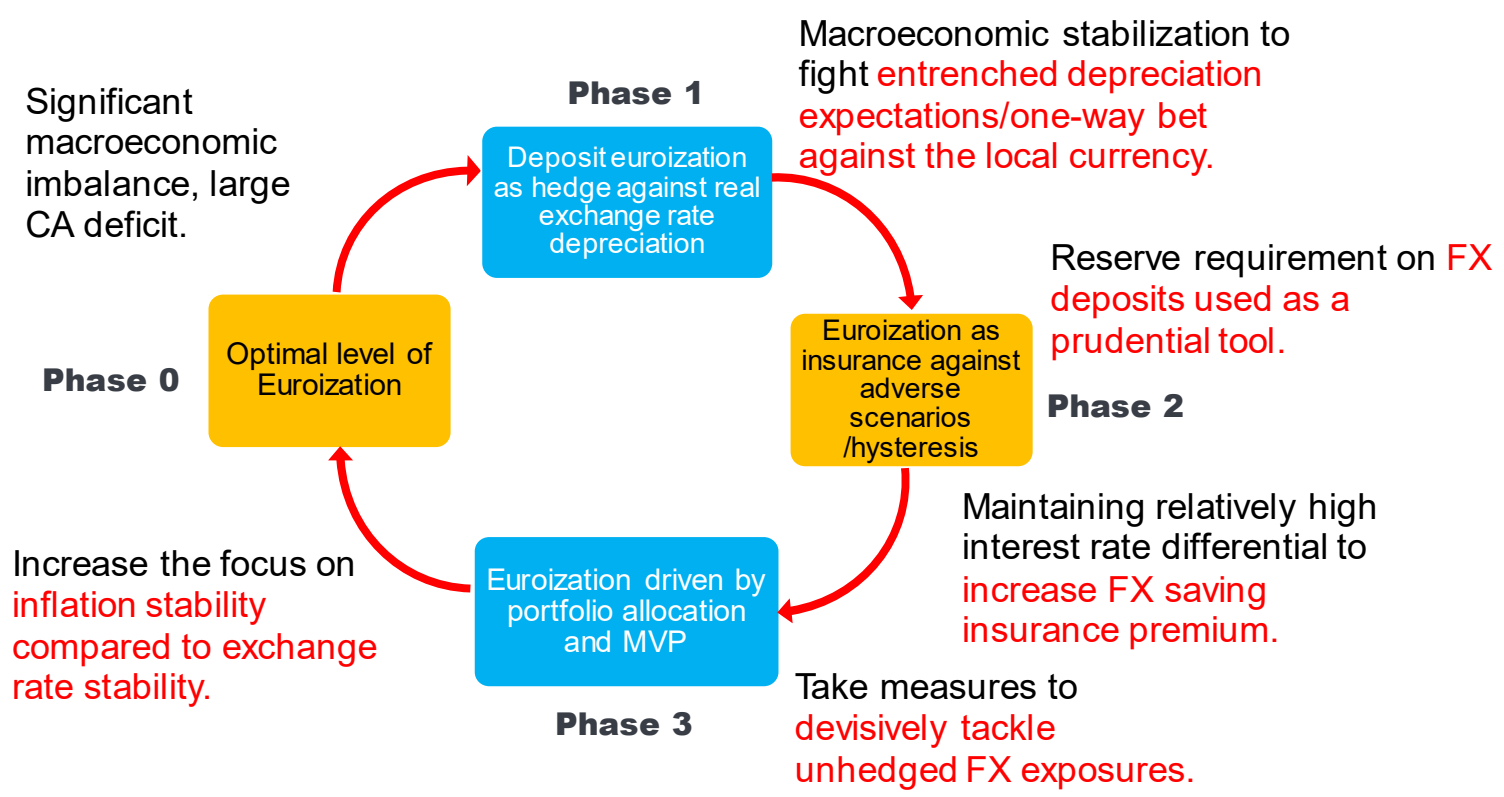

Source: authors.

Developing the local capital markets is important to promote the local currency. A more developed capital market provides more investment opportunities in local currency, thereby reducing the incentives for asset euroization. Such markets also facilitate banks' term funding in local currency at lower costs and establish a yield curve along which loans can be priced, thereby supporting the supply of local currency-denominated loans, at longermaturity and at a fixed interest rate.

On the supply side, the government security market leads the way to capital market development. Initiatives to develop the government securities markets consist of (i) diversifying the base of investors in government securities, including a conscious effort to attract foreign investors, which are more likely to participate in the secondary market; (ii) developing the secondary market, as well as the repo market, to make it easier to fund and carry positions in government securities denominated in local currency; (iii) encouraging long-term savings in local currency, via the promotion of pension funds, to create a demand for long-term securities. The ultimate goal is to establish a government yield curve along which bank and corporate issuances could be priced.

On the demand side, strong macroeconomic performances are expected to improve the confidence in saving in local currency and, thus, the demand for longer-term investment in local currency. A well-designed government debt strategy would dovetail with the increase in the demand for investment in local currency inasmuch as it provides more options for investment in local currency-denominated securities, thereby boosting the development of the local currency-denominated capital market. That said, developing a deep and liquid capital market in a small open economy would likely be challenging. 
The third challenge, which is a medium-term endeavor, is to gradually reduce the weight given to the exchange rate in monetary policy decisions. At this stage, it is assumed that the fear of floating due to unhedged exposures to the exchange rate has been largely addressed via prudential measures (see below). An increase in two-way risk in the market (i.e., two-way exchange rate volatility) transfers the exchange rate risk and cost of hedging against it to economic agents. This transfer, in turn, reduces their appetite for unhedged exposures and fosters the development of the market for exchange rate risk hedging instruments.

A more flexible exchange rate allows central banks to focus their efforts on stabilizing inflation and inflation expectation. This, in turn, reduces the MVP, thereby encouraging a reallocation of savings in favor of domestic currency assets. This is phase 3 of the euroization cycle presented in Figure 12. This sequence of macroeconomic policies is expected to bring euroization back to its optimal level over the medium to long term.

\section{B. Prudential Measures}

The role of prudential measures is primarily to reduce financial stability risks due to financial euroization by raising awareness of the exchange rate risks, by limiting euroization to the areas of the economy that can better withstand exchange rate fluctuations, and by increasing the buffers against exchange rate fluctuations. Prudential measures force banks to implement a prudent management of liquidity and credit risks associated with foreign currency intermediation.

Prudential measures indirectly make domestic intermediation financially more attractive to the public. As local currency intermediation presents less credit and liquidity risks than foreign currency intermediation, local currency intermediation spread should be narrower than foreign currency intermediation spread, if the risks are well priced. As discussed before, this is not yet the case in Albania. Prudential measures would tighten the local currency intermediation spread vis-à-vis the foreign currency intermediation spread if they correct foreign currency intermediation mispricing due to an underestimation of its risks.

On the deposit side, the reserve requirement plays an important prudential role. As central banks have limited capacity to provide emergency liquidity in foreign currency, banks are expected to keep a relatively high level of high-quality liquid assets to cover their deposits. The reserve requirement forces banks to keep a certain percentage of their foreign currency deposits in foreign currency denominated liquid assets of very high quality (i.e., reserves) available at the central bank. If maintained on a permanent basis (blocked at the central bank), the reserve requirement is likely to provide more resources than any type of deposit insurance scheme to repay some of the foreign currency deposits in case of bankruptcy. In addition, a high enough reserve requirement contributes to maintain a prudent leverage in foreign currency, e.g., a loan-to-deposit ratio of less than 80 percent, which-in turnencourages banks to charge a higher interest rate spread between foreign currency deposits and loans.

The different purposes of the reserve requirements, depending on the denomination of their respective bases, entail different required reserve ratio. The reserve requirement on foreign currency deposits, which fulfills prudential functions, is usually higher than the reserve 
requirement on domestic currency deposits, which contributes to domestic liquidity management and often does not require a similarly high reserve requirement ratio.

Other measures could contribute to internalize the risks associated with foreign currency deposits in banks' pricing. More demanding liquidity coverage ratios, for instance, could be imposed on foreign currency liabilities.

On the lending side, the purpose of prudential measures is to limit borrowing in foreign currency to hedged borrowers and to the most creditworthy unhedged borrowers. In addition, they should ensure that borrowers and the banks themselves have sufficient buffers to absorb possible exchange rate-induced losses.

The most important target of prudential measures is unhedged borrowing. It would be counterproductive to encourage companies with revenues in foreign currency to borrow in local currency, thereby creating a currency mismatch. The first step is, thus, to identify unhedged borrowers, which often requires that the supervisor establishes a common definition of unhedged borrowing and requests banks to monitor unhedged borrowing among their clients. In addition, it is often required that banks formally inform their clients of the risks related to unhedged borrowing in a clear, understandable, and possibly quantified manner. It is also often required that banks offer alternative borrowing plans in local currency.

Banking supervisors have several tools to limit borrowers' exposures to exchange rate risk.

- The first line of defense is to set a maximum debt-service-to-income ratio on unhedged borrowing in foreign currency able to absorb large exchange rate depreciation, thereby providing a larger cushion before debt-servicing capabilities are impaired. This should lower the probability of default of unhedged borrowers and restrict this practice to the most creditworthy borrowers.

- The second line of defense consists in imposing a lower maximum loan-to-value ratio on foreign currency loans to limit the loss given default on foreign currency loans. The loss given default is the share of the asset that is lost if a borrower defaults (i.e., debt servicing capability is impaired), factoring in the proceeds of the sale of the collateral made available by this borrower.

- Finally, the third line of defense involves requiring additional capital or setting a higher risk weight on foreign currency loans, which serves to absorb possible banks' losses due to the default of unhedged borrowers pursuant to a large exchange rate depreciation. The higher risk weight on foreign currency loans to unhedged borrowers increases the interest rate that banks charge their clients to compensate for higher capital cost, thereby reducing the apparent financial appeal of foreign currency loans vis-à-vis domestic currency loans. 


\section{Conclusion}

This paper is the first attempt to approximate the optimal level of financial euroization in the literature on euroization. The estimated benchmark reveals that the optimal level of euroization could be high in small economies with relatively high remittances flows, such as Albania. In addition, it provides a useful reference to estimate the euroization level below which the costs of deeuroization, such as financial disintermediation, may outweigh its benefits in terms of monetary policy transmission and financial stability.

The paper introduces an euroization lifecycle. It identifies euroization causes and contributing factors in the different phases of the euroization lifecycle. This paper argues that the different factors come into play with an importance that depends on the position of the economy in the euroization lifecycle. This identification of causes and contributing factors should facilitate the selection of the corresponding policy levers to use in the different phases to address euroization.

Euroization is mainly driven by macroeconomic factors. Deeuroization polices would need to build a track record of low and stable inflation associated with two-way exchange rate volatility to encourage savings in domestic currency. This is a long-term endeavor as the patterns of savings and investments change only gradually. Inflation targeting and exchange rate flexibility contribute to attaining these policy objectives if consistently implemented.

On the other hand, prudential measures indirectly influence the public attitude vis-à-vis financial euroization. They make the local currency intermediation financially more attractive inasmuch as they force banks to correct the underpricing of financial euroization risks. This paper encourages supervisors to tackle decisively and immediately the liquidity and credit risks, arising from euroization, to avoid costly financial crises, without waiting for the impact of strong macroeconomic performances to reduce financial euroization.

The conceptual framework developed in this paper helps to coordinate the macroeconomic policies and prudential measures, which are tightly intertwined in the pursuit of deeuroization objectives. For instance, addressing forcefully the fear of floating due to unhedged exposures to the exchange rate risk in the economy supports the transition to a more flexible exchange rate, which is a critical step in macroeconomic policies aimed at deeuroization.

The BoA has developed a comprehensive deeuroization strategy with the support of the IMF technical assistance funded by the Swiss government. The Albanian strategy is in line with the model hereby presented to address the financial stability risks deriving from euroization while macroeconomic stability is preserved via sound and sustainable policies. The target of the Albanian deeuroization strategy in the medium term is the empirical benchmark of optimal euroization as estimated in this paper.

There is a strong demand among IMF members for guidance on promoting the use of their domestic currency in lieu of financial intermediation in foreign currency. The conceptual framework and the policy suggestions in this paper could, therefore, provide a reasonable medium-term target for deeuroization policies (the empirical benchmark) and inspire the development of deeuroization strategies in other countries. 


\section{REFERENCES}

Basso, H., O. Calvo-Gonzalez, and M. Jurgilas, 2007, "Financial Dollarization: the Role of Banks and Interest Rates,” ECB Working Paper No. 748.

Beckmann, E., 2017, "How does foreign currency debt relief affect households' loan demand? Evidence from the OeNB Euro Survey in CESEE," Focus on European Economic Integration Q1/17, 8-29.

Bini Smaghi, L., 2007, “Central bank independence: from theory to practice,” speech by Lorenzo Bini Smaghi, Member of the Executive Board of the ECB, at the conference Good Governance and Effective Partnership Budapest, Hungarian National Assembly, April 19, 2007.

Bogetic, Z., 2000, “Official Dollarization: Current Experiences and Issues," Cato Journal 20(2), 179-213.

European Systemic Risk Board, 2011, "Recommendation on foreign exchange lending of 21 September 2011," ESRB/2011/1.

Feige, E., and J. Dean, 2004, "Dollarization and euroization in transition countries: currency substitution, asset substitution, network externalities and irreversibility," in Monetary Union and hard pegs: effects on trade financial development and stability, New York and Oxford, Oxford University Press.

Galindo, A., and L. Leiderman, 2005, "Living with Dollarization and the Route to Dedollarization,” Inter-American Development Bank Working Paper No. 526.

Herrera, L.O and R. Valdés, 2005, "Dedollarization, indexation, and nominalization: the Chilean experience," Journal of Policy Reform, Vol. 8, No. 4.

International Monetary Fund, 2016, "Guidance Note on the Assessment of Reserve Adequacy and Related Considerations," (Washington: International Monetary Fund).

Ize, A., and E. Levy-Yeyati, 2003, "Financial Dollarization,” Journal of International Economics, Vol. 59, issue 2, 323-347.

Kokenyne, A., J. Ley, and R. Veyrune, 2010, "Dedollarization,” IMF Working Paper No. $10 / 188$.

Levy-Yeyati, E., 2003, "Financial dollarization: where do we stand?" paper presented at conference "Financial dedollarization: policy options," IADB, Washington, DC, December 1-2, 2003.

McKinnon, R., 1963, "Optimum Currency Areas," The American Economic Review, Volume 53, No. 4, 717-725. 
Mundell, R., 1961, “A Theory of Optimum Currency Areas," American Economic Review, No. 51, 657-664.

Oesterreische Nationalbank, 2016, "OeNB Euro Survey. The euro in Central, Eastern and South Eastern Europe," Available on the Oesterreische Nationalbank website.

Tase, M., 2005, "Currency substitution in the Albanian economy," Workshop on Monetary policy issues and inflation forecasting, Tirana, January 26-27, 2005.

Uribe, M., 1997, "Hysteresis in a simple model of currency substitution," Journal of Monetary Economics, Vol. 40, Issue 1. 185-202.

Weymouth, S., 2007, "Political Institutions, Policy Instability, and Financial Dollarization," University of California. 